\title{
Article
}

\section{Differentiation and Changes of Household Electricity Prices in EU Countries}

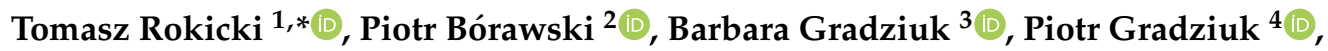 \\ Aldona Mrówczyńska-Kamińska ${ }^{5}{ }^{\infty}$, Joanna Kozak ${ }^{5}$, Danuta Jolanta Guzal-Dec ${ }^{6}$ and Kamil Wojtczuk ${ }^{7}$
}

check for

updates

Citation: Rokicki, T.; Bórawski, P.;

Gradziuk, B.; Gradziuk, P.;

Mrówczyńska-Kamińska, A.; Kozak,

J.; Guzal-Dec, D.J.; Wojtczuk, K.

Differentiation and Changes of

Household Electricity Prices in EU

Countries. Energies 2021, 14, 6894.

https://doi.org/10.3390/en14216894

Academic Editor: Victor Manuel

Ferreira Moutinho

Received: 23 September 2021

Accepted: 16 October 2021

Published: 21 October 2021

Publisher's Note: MDPI stays neutral with regard to jurisdictional claims in published maps and institutional affiliations.

Copyright: (c) 2021 by the authors. Licensee MDPI, Basel, Switzerland. This article is an open access article distributed under the terms and conditions of the Creative Commons Attribution (CC BY) license (https:/ / creativecommons.org/licenses/by/ $4.0 /)$.
1 Institute of Economics and Finance, Warsaw University of Life Sciences, 02-787 Warsaw, Poland

2 Department of Agrotechnology, Agricultural Production Management and Agribusiness, Faculty of Land Management and Agriculture, University of Warmia and Mazury in Olsztyn, 10-719 Olsztyn, Poland; pboraw@uwm.edu.pl

3 Department of Management and Marketing, Faculty of Agrobioengineering, University of Life Sciences in Lublin, Akademicka 13, 20-950 Lublin, Poland; barbara.gradziuk@up.lublin.pl

4 Polish Academy of Sciences Institute of Rural and Agricultural Development, 00-330 Warsaw, Poland; pgradziuk@irwirpan.waw.pl

5 Department of Economics and Economic Policy in Agribusiness, Faculty of Economics, Poznan University of Life Sciences, Wojska Polskiego 28, 60-637 Poznań, Poland; aldonam@up.poznan.pl (A.M.-K.); joanna.kozak@up.poznan.pl (J.K.)

6 Department of Economy, Faculty of Economic Sciences, Pope John Paul II State School of Higher Education, Sidorska 95/97, 21-500 Biała Podlaska, Poland; d.guzal-dec@dydaktyka.pswbp.pl

7 GazTank Małgorzata Wojtczuk, ul. Mickiewicza 17A, 05-816 Michałowice, Poland; wojtczukkamil@gmail.com

* Correspondence: tomasz_rokicki@sggw.edu.pl; Tel.: +48-22-59-342-59

\begin{abstract}
The paper's main purpose is to identify the differentiation and variation of electricity prices for households in EU countries. The specific objectives are to highlight the directions and differentiation of price changes in EU states, determine the degree of volatility (or stability) of electricity rates, and establish the correlation between electricity prices for household consumers and economic and energy parameters. All members of the European Union were chosen for this project as of 31 December 2019 (28 countries). The analyzed period covered the years 2008-2019. The source of collected information was the thematic literature review and the data from Eurostat. Descriptive, tabular and graphical methods, constant-based dynamics indicators, coefficient of variation, Kendall's tau correlation coefficient, and Spearman's rank correlation coefficient were used to analyze and present the materials. It was determined that higher electricity prices for households in the EU states were associated with better economic parameters. Developed countries must have higher energy rates because they will ensure energy transformation, i.e., implementing energy-saving technologies. In the EU, electricity prices for household consumers showed little volatility, but that variability increased in line with the surge of the volume of household energy consumption.
\end{abstract}

Keywords: electricity prices; households; EU countries; directions of price changes

\section{Introduction}

Electricity is obtained by burning fossil fuels such as hard coal, lignite, oil, and natural gas. In addition to such conventional sources, energy is also obtained from renewable resources such as wind, solar power, water, and geothermal heat. Such heterogeneity results in different energy production costs. There are also variabilities between countries regarding the structure of energy sources [1-10].

The creation of a common electricity market in the European Union has been going on for almost 30 years. Actions and regulations are mainly based on EU agreements and objectives. EU energy policy is based on three pillars: competition, security of supply, and sustainable development. Energy security includes aspects such as availability of supply, affordability, and sustainability [11-13]. There are also important goals such as reducing 
greenhouse gas emissions, increasing the consumption of energy produced from renewable sources, improving energy efficiency, and expanding electricity connections [14-20]. On the one hand, the electricity policy focuses on the liberalization of the entire sector, while on the other hand, it concentrates on development towards more innovative and more sustainable electricity sector [21-27]. All goals were introduced gradually and evolved. The first energy package in 1996 assumed the separation of generation from transmission and distribution, competition in electricity generation, opening the market for large consumers, non-discrimination in access to the grid, and the obligation to provide a safe, reliable, and efficient service by the distribution system operator [28]. The second energy package of 2003 dealt with competition in the retail market for households, unbundling of network activities, the creation of national electricity regulators, and the obligation of the distribution system operator to provide information enabling efficient access to the network [29]. The third energy package assumed the definition of retail supplier switching procedures, the procedures for ownership unbundling of transmission system operators, emphasizing the importance of modernizing the electricity distribution network, and the significance of smart grids and energy efficiency [30]. The 2010 strategy focused on achieving energy efficiency targets and implementing low-carbon technologies [31]. In 2011, targets were set for 2050 for a low-carbon economy [32]. Another document from 2015 concerned supporting the previous goals in the field of EU energy policy [33]. One should also mention the 2016 document on renewable electricity [34].

Electricity is a classic example of a homogeneous commodity. Homogeneous goods (services) can be characterized as physically indistinguishable or perceived as identical in the eyes of the consumer. Since the customer cannot differentiate one product from another it becomes very hard for the seller to compete. Therefore, the consumer can compare prices in different areas and periods. Since 1999, customers have been free to choose their electricity supplier. They have a very large selection in this regard. The area is served by a single operator and by a large number of participants. Energy rates can even vary within the same area. It is the customer who has to seek the best price for himself actively. However, studies show that such activities were not very common. Most often, customers were served by the local operator. Studies have found that only households informed about the tariffs are sensitive to price modifications, in the case of uninformed households the electricity demand is completely price inelastic [35-42]. That is why the EU is taking action to change this. Citizens should take action and be responsible for the energy transition by actively participating in the market. They can choose tariffs as needed but also try to change their electricity consumption patterns. For example, they can use energy to a greater extent during periods of lower grid load. However, information services are needed to achieve these effects [43-48].

In the future, consumers will be prosumers, i.e., they will produce electricity on their own and feed its surplus into the grid. Micro-networks will be created that are isolated or connected to the main network. As a result, prosumers will achieve better economic efficiency by reducing operating costs, and at the same time, contributing to the improvement of the natural environment. However, such transformation takes time [49-60].

Electricity prices is the topic of research in the field of wholesale markets. Many researchers are concerned with the electricity rates in the futures markets. Therefore, energy is the subject of the trade [61-65]. There is very little research about retail prices that relates to private households. In Moreno et al. [66], the authors investigate the determinants which affect the electricity rates in wholesale markets. However, they indicate that the impact on the determinants of household prices is unclear. In the studies by Verbic et al. [67] the relationship between the retail electricity price and energy intensity was examined, but only for households consuming 2500-5000 kWh per year. Waddams Price and Zhu [68], in the paper on the example of the British market, state that the retail electricity market has been subject to free-market laws since the end of the 20th century. Energy distribution companies were divided into regions, but they could also compete in other territories. Nevertheless, companies focused more on securing their position in their region than on 
acquiring new clients in other territories. It also caused problems, such as a greater impact on energy prices in a given area by one or two companies. As a result, the prices were higher than in the case of competition with multiple companies. Additionally, according to Giulietti et al. [41] the problem is the behavior of consumers who consider it too costly to find a new electricity supplier. Littlechild [69] states in his research that competition in the market is often understood as price competition. The European Commission uses this approach in relation to the retail electricity market. A well-functioning market will require some form of regulatory intervention, but the legal constraints should not be strong.

In many countries, energy prices are part of electoral policies and promises. For example, in Great Britain, the Conservative party promised a tariff protection cap and the Labor party a price cap that would ensure low energy rates [70]. Therefore, there are differences between countries. Another reason is price asymmetry, i.e., prices are more responsive to rising costs than falling costs. With rising electricity rates, households look more for a cheaper solution than falling prices [71-77]. Additionally, households are generally reluctant to change their electricity contract. In Sweden, only $15 \%$ of households changed their contracts every year. It is also a problem for policymakers [78]. There are significant financial benefits to shifting tariffs [79]. The moment of changing the contract is also important [80]. There are very few studies that determine that consumers are not paying attention to the price changes. These customers also do not want to receive personalized information on their energy consumption and costs. Such a situation takes place only until a certain threshold is exceeded. Then there is a reduction in energy absorption [81-83]. Other studies confirm the impact of personalized information sent directly to a specific consumer on reducing energy consumption. This effect continued for a long time. Information comparing the absorption of electricity in a given household to neighbors or the national average and moral factors were of particular importance on energy consumption. The price factors were of much less importance [84-91]. This research can influence the choices of decision-makers in the scope of proposed tariffs and shaped pricing policy. Such solutions are already used in the Western Europe [92-94].

There is a lack of research relating retail electricity prices to the parameters of the economy and other factors related to the energy sector. The presented article may fill the resulting research gap.

The paper's main objective is to identify the differentiation and variation of electricity prices for households in EU states. The specific goals are to show the directions of price changes and differentiation in this regard in EU countries, determine the degree of volatility (or stability) of electricity prices, and establish the correlation between electricity prices for household consumers and economic and energy parameters.

Determining the regularities that are present may be useful for policymakers with influence on the electricity markets. The research can also be treated as preliminary for further analysis. Taking the example of the most developed economies, it can be determined what future electricity retail prices in developing countries may become. As a rule, models and regularities are duplicated. Much depends on the level of economic development of the country. Additionally, the division of households into groups shows how the retail price degression is applied depending on electricity consumption. This phenomenon occurred in most EU states. Of course, there were exceptions. Based on these studies, in-depth investigations can be made in the future.

Two hypotheses were put forward in the paper. According to the first one, the level of electricity prices intended for households in the EU states was closely related to the economic situation in a given country, but the strength of this relationship decreased with higher electricity absorption in households. The economic situation was determined by parameters such as: total and per capita GDP value, total and per capita household expenditure, the size of exports and imports. The second hypothesis was that electricity prices for household consumers showed little volatility, but this variability increased with the growth in household energy consumption, especially in the group of economically developed countries. 
The limitation of the study is the availability of information. Data was aggregated by country. There were no complete details available for specific regions. Additionally, the data was provided on a semi-annual basis, in line with reporting to statistical offices. In most EU countries, retail energy prices are rarely changed. Therefore, the information used can be considered as sufficient. The division into groups of households according to the amount of energy consumption during the year was also imposed. The given limitations should not affect the interpretation of the obtained test results.

\section{Materials and Methods}

All members of the European Union were chosen for this project as of 31 December 2019 (28 countries). The analyzed period covered the years 2008-2019. The sources of collected information were the thematic literature review and the data from Eurostat. Descriptive, tabular and graphical methods, constant-based dynamics indicators, coefficient of variation, Kendall's tau correlation coefficient and Spearman's rank correlation coefficient were used to analyze and present the materials.

The research was divided into stages. Figure 1 shows a diagram of the conducted research.

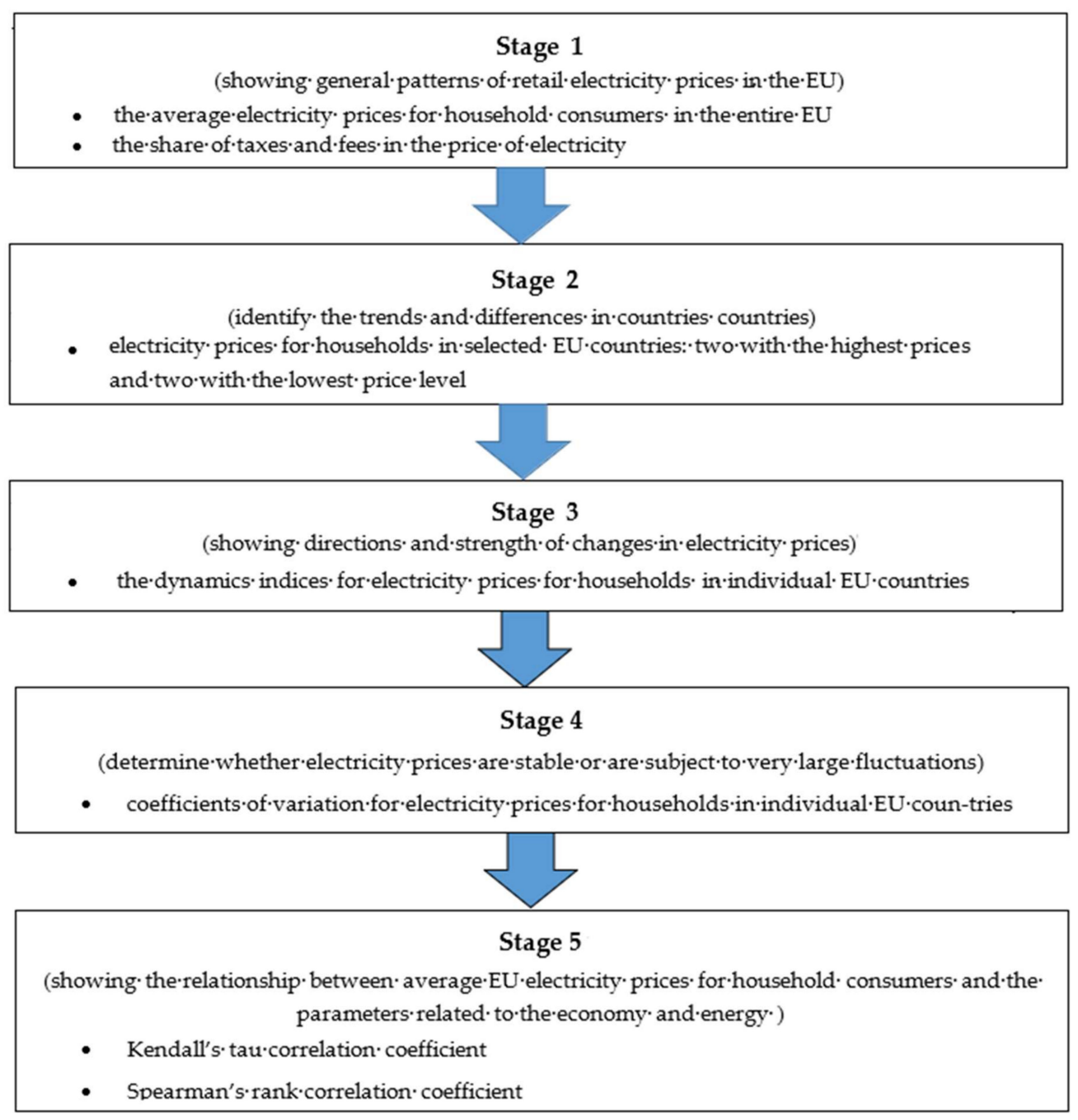

Figure 1. Diagram of the conducted research.

The first stage of this project portrays the average electricity prices for household consumers in the entire EU in 2008-2019. In addition, the share of taxes and fees in the price of electricity was also presented. In both cases, the prices were depicted in five groups of households differing in the volume of electricity consumption during the year. This 
approach was also used in subsequent stages of the research. This section provides an overview of the general patterns of retail electricity prices in the EU.

In the second phase of the research, electricity prices for households in selected EU countries were presented, i.e., two with the highest prices and two with the lowest price level. As a result, it was possible to determine trends and differences in countries that are on two different poles in the level of retail prices of electricity.

In the third stage, the dynamics indices for electricity prices for households in individual EU countries were estimated. As a result, the data concerning strength and directions of changes in electricity rates was obtained.

The dynamics index with a fixed base can be estimated as follows [95]:

$$
i=\frac{y_{n}}{y_{0}} \text { or } i=\frac{y_{n}}{y_{0}} \cdot 100 \%
$$

where:

$y_{n}$ - the amount of the occurrence in a certain period,

$y_{0}$ - the amount of the occurrence during the reference period.

In the fourth phase, the variation coefficients for electricity prices for households in individual EU states were calculated. As a result, it was possible to determine whether electricity prices are stable or are subject to substantial fluctuations.

The variation coefficient marked as $C_{v}$ eliminates the unit of assessment from the standard deviation of a set of digits. It is done by obtaining the quotient of standard deviation divided by the arithmetic mean. Formally, for sequence of $N$ numbers, the variation coefficient is calculated as follows [96]:

$$
C_{v}=\frac{S}{M}
$$

where:

$S$ - the standard deviation from the exemplar set of numbers,

$M$-the arithmetic mean of the exemplar set of numbers.

In the fifth stage, the relationship between average EU electricity prices for household consumers and the parameters related to the economy and energy were analyzed. The parameters were purposefully selected based on the literature review. Introduced parameters indicate all the most significant aspects associated with the economy of a particular country and the level of energy development. Thanks to this research project, it is possible to determine the importance of parameters and their strength of association with retail electricity prices. In this phase of the project, two non-parametric tests were applied to define the correlation between the variables. The former one is Kendall's tau correlation coefficient. It is established on the difference between the probability that two variables fall in the same sequence (for the interpreted data) and the probability that these factors are different. This coefficient fluctuates in the range of values $<-1,1>$. Value 1 means complete match, value 0 indicates no match of order, and value -1 indicates the complete opposite. The Kendall coefficient suggests not only the robustness but also the direction of the interdependence. It is a good tool to represent the similarity of the ordered sets of data. The following formula can be used to calculate Kendall's tau correlation coefficient [97]:

$$
\tau=P\left[\left(x_{1}-x_{2}\right)\left(y_{1}-y_{2}\right)>0\right]-P\left[\left(x_{1}-x_{2}\right)\left(y_{1}-y_{2}\right)<0\right] .
$$

The given formula evaluates Kendall's tau based on a statistical sample. First, all possible pairs of the observed population are combined. Next, the pairs are split into three possible units:

$P$-compatible pairs, when the analyzed factors within two observations fluctuate in the same trend, i.e., either in the first observation both are higher than in the second, or both are less significant; 
$Q$-incompatible pairs, when the factors differ against each other in the opposite trend, i.e., one of them is more significant for this observation in the pair, while the other is smaller;

$T$-related pairs in the case of one of the variables having equal values in both observations.

The Kendall tau coefficient is then calculated from the following formula:

$$
\tau=\frac{P-Q}{P+Q-T}
$$

Moreover,

$$
P+Q+T=\left(\frac{N}{2}\right)=\frac{N(N-1)}{2}
$$

where:

$N$-the sample volume.

The pattern can be quantified as:

$$
\tau=2 \frac{P-Q}{N(N-1)} .
$$

The latter form of non-parametric tests is the Spearman's rank correlation coefficient, which describes the strength of the correlation of two characteristics. It is used to analyze the relationship between quantitative traits for the small amount of observations. Spearman's rank correlation coefficient is estimated according to the following formula [98]:

$$
r_{S}=1-\frac{6 \sum_{i=1}^{n} d_{i}^{2}}{n\left(n^{2}-1\right)}
$$

where:

$d_{i}$-the disparity between the range of the corresponding factors $x_{i}$ and feature $y_{i}$ $(i=1,2, \ldots, n)$

The Spearman's rank coefficient fluctuates in the range $-1 \leq r_{s} \leq+1$. A positive number indicates a positive correlation, while a negative digit indicates a negative correlation. The more similar modulus (absolute value) of the correlation coefficient, the more robust the correlation between analyzed variables.

The following techniques were used for data presentation: descriptive, tabular, and graphic.

\section{Results}

\subsection{Medium Electric Prices for Households in the EU Together}

Electricity prices for households in the member states of European Union are grouped by category according to the amount of consumption. There are five clusters. Firstly, the average electricity prices for household customers in all EU countries in 2008-2019 are presented (Figure 2). The prices were given on a semi-annual basis. By far the highest electricity prices were in the case of the lowest consumption, up to $1000 \mathrm{kWh}$ per year. The more electricity was consumed by the households, the lower the price for $1 \mathrm{kWh}$. Such a regularity seems logically justified and results from the economy of scale. Nevertheless, the disproportions between prices in individual classes were visible, especially in households consuming the least energy and those with the highest consumption. In the following years, the differences deepened. In 2008-2019, energy prices in households consuming up to $1000 \mathrm{kWh}$ increased by $53 \%$ to EUR 0.38 per $\mathrm{kWh}$. This increase was slightly smaller in the next group (from 1000 to $25,000 \mathrm{kWh}$ ) (46\%). In the next group, i.e., 2500 to $5000 \mathrm{kWh}$, prices increased by $37 \%$, and in the following two (from 5000 to $15,000 \mathrm{kWh}$ and above $15,000)$. $\mathrm{kWh}$ ) by 33 and $30 \%$ respectively. 


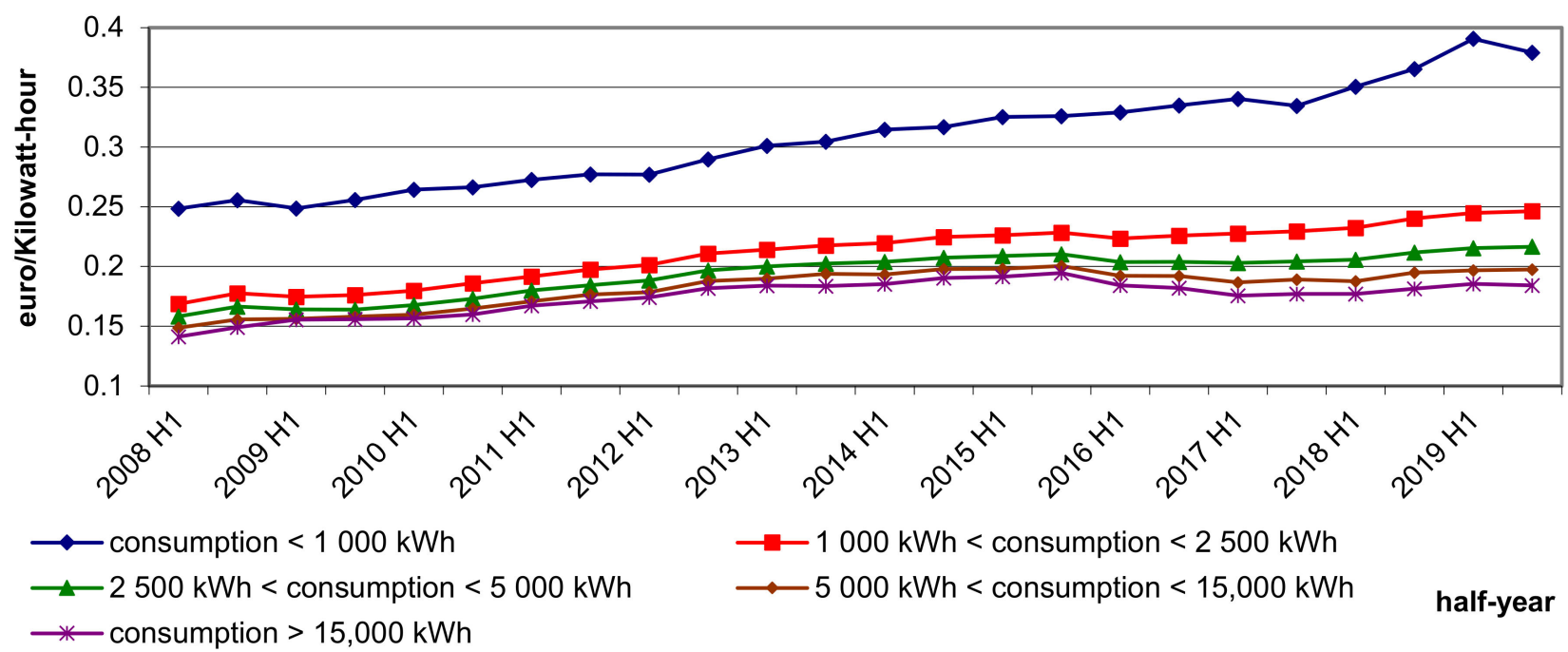

Figure 2. Electricity prices for private customers in European Union in 2008-2019.

The share of taxes and tariffs in the price of electricity supplied to private households was also determined (Figure 3). It was by far the highest in the case of households with the highest electricity consumption. A regularity was found according to which the higher the consumption of electricity, the more taxes and charges were included in the price of energy. Additionally, the disproportions deepened. In 2008, in households consuming up to $1000 \mathrm{kWh}$ in the price of energy, there were $29 \%$ in taxes and fees, and in 2019 as much as 32\%. On the other hand, in households with the highest electricity consumption (over 150,000 kWh), these shares amounted to 40\% in 2008 and 43\% in 2019, respectively. It can be concluded that higher energy consumption was burdened with relatively higher taxes, although the unit energy price was lower compared to households with low energy consumption.

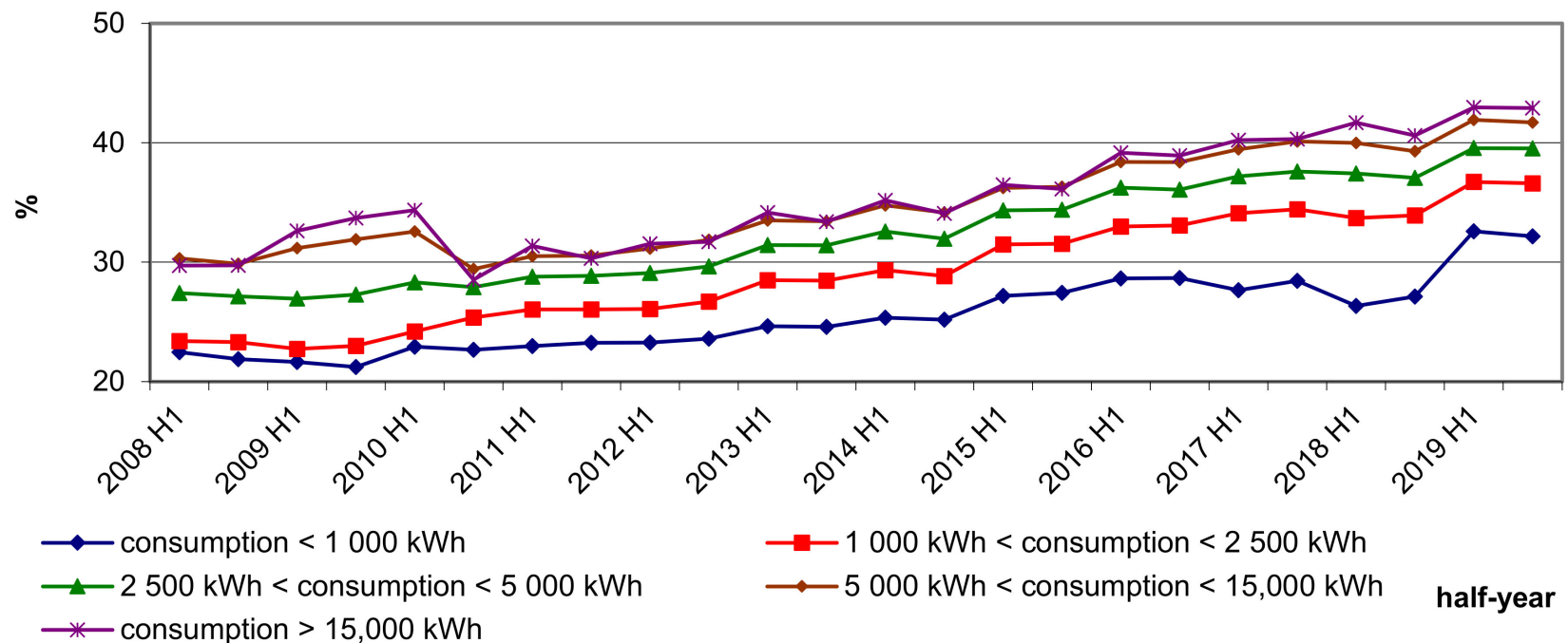

Figure 3. The contribution of levies and taxes in electricity prices for private customers in European Union in 2008-2019.

\subsection{Electric Prices for Households in Selected EU Countries}

Electricity prices for private households varied. It could also be the case in the direction of changes. There was no country with the highest electricity prices in each consumption group. In order to select examples of countries for a more detailed analysis, the investments received by individual countries in each of the groups in terms of energy consumption were compared. The highest electricity prices for households were in Germany. In 2019, this 
country was in the first positions in the groups of 1000-2500 kWh and 5000-15,000 kWh, second in 2500-5000 kWh and above 15,000 kWh, and fourth in the group below $1000 \mathrm{kWh}$. Another state with very high electricity prices was Denmark, ranking 1st, 2nd, 3rd, 4th, and 11th in individual groups. The same was done in the case of countries with the lowest electricity prices for households. It was a little easier in this case. Bulgaria was last in the EU in all groups in terms of consumption volume, while Hungary was in the penultimate place respectively.

In Germany, the electricity prices intended for households in the group with the smallest consumption volume, i.e., up to $1000 \mathrm{kWh}$, were the highest (Figure 4). Additionally, the differences between extreme groups deepened. Electricity prices in Germany in the $1000 \mathrm{kWh}$ group increased by $34 \%$, and in the over $15,000 \mathrm{kWh}$ group by only $24 \%$. The share of taxes and tariffs in the price of electricity in Germany in 2008 was 31\% in the group with consumption up to $1000 \mathrm{kWh}$ and $41 \%$ in the group with consumption above $15,000 \mathrm{kWh}$. In 2019, it was 40 and 61\%, respectively. Therefore, it can be concluded that the increase in electricity prices in Germany was largely due to the increase in taxes and fees.

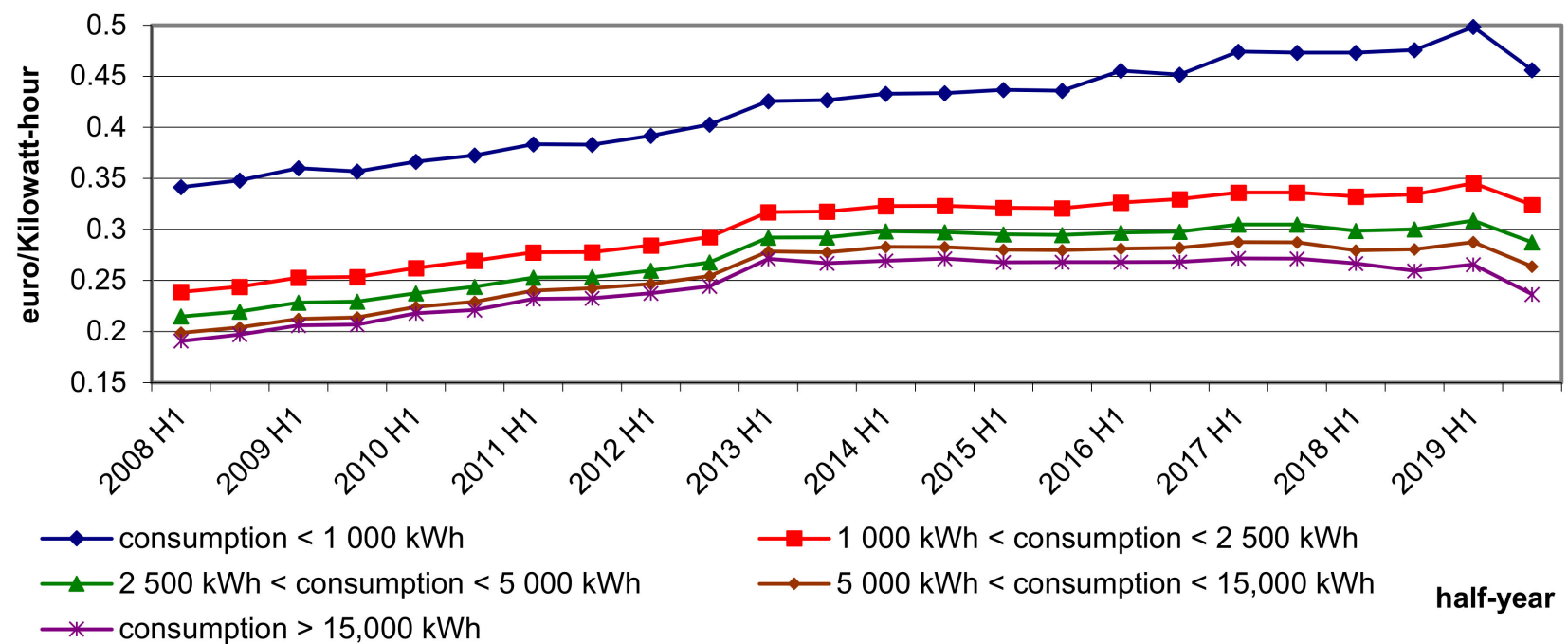

Figure 4. Electricity prices for private customers in Germany in 2008-2019.

In Denmark, in 2008-2019, there was a 9\% drop in electricity prices for private households consuming the highest volumes, i.e., over 15,000 kWh (Figure 5). In the group with the lowest consumption, up to $1000 \mathrm{kWh}$, electricity prices increased by $26 \%$. As a result, the disparities widened even more. In the case of Denmark, the prices in 2008-2014 in the groups with the lowest energy consumption, i.e., up to $1000 \mathrm{kWh}$ and $1000-2500 \mathrm{kWh}$, were at the same level. It was similar in the given period in the two groups with the highest consumption, i.e., 5000-15,000 kWh and above 15,000 kWh. Since 2015, there have been differences in electricity prices between the five groups differing in terms of consumption. In Denmark, in 2008, in the price of electricity intended for households, taxes and charges accounted for $54 \%$ of this price in the group with consumption up to $1000 \mathrm{kWh}$, and $59 \%$ in the group above 15,000 kWh. In 2018, it was 55 and 56\%, respectively. The tax burdens and charges for the electricity price in the group consuming more than 15,000 $\mathrm{kWh}$ decreased and slightly increased in the group with the lowest energy consumption.

One of the lowest electricity prices for private households was in Hungary (Figure 6). In addition, in this state in 2008-2019, there was a decrease in energy prices in all groups. On average, it was 30\%, but it was the highest in energy consumption above 15,000 kWh (a decrease by $33 \%$ ). Additionally, the differentiation by the group has become less and less visible. Price levels, especially in 2019, were almost identical. In Hungary, there was also a small fraction of taxes and tariffs in the price of electricity intended for private households. In 2008, it was $17-18 \%$ in individual groups, and in $2019,21 \%$. Still, it must be remembered 
that this is a relative share, and energy prices have fallen. The tax burden on consumers has not changed in real terms, taking into account only the absolute value.

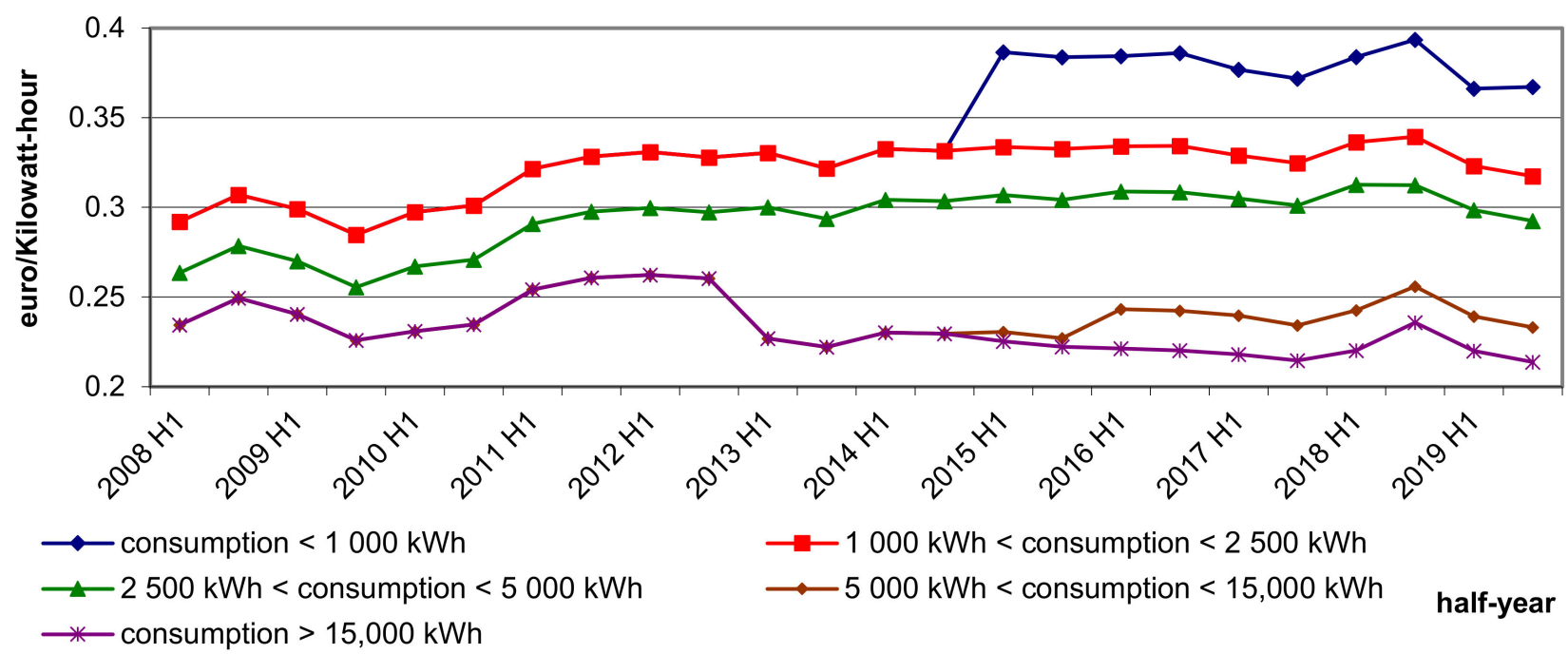

Figure 5. Electricity prices for household consumers in Denmark in 2008-2019.

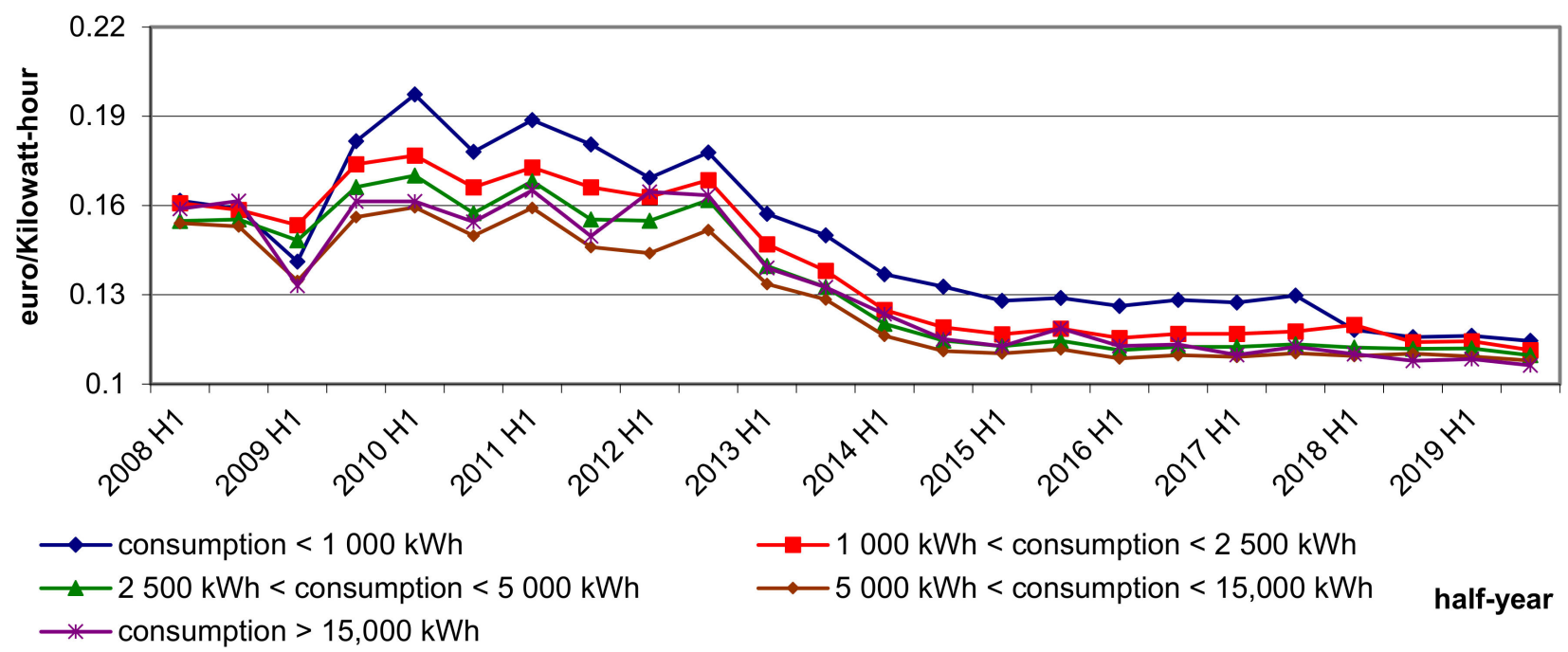

Figure 6. Electricity prices for private customers in Hungary in 2008-2019.

Definitely, the lowest prices of electricity for households were in Bulgaria (Figure 7). Although in 2008-2019 electricity prices soared by $32-37 \%$ in individual groups, the prices were still the lowest in the entire EU. In the case of Bulgaria, there were also no big differences in electricity prices between private households with different consumption volumes. It also results from the approach of the state and energy companies to the pricing policy. The share of taxes and charges in the energy price did not change in this country and amounted to $17 \%$.

The presented examples of countries show some models of electricity pricing for households. In countries with the highest electricity prices, there was a significant differentiation of the price level depending on the volume of energy consumption. Additionally, prices were systematically growing there, and there was a very large share of taxes and fees in the price of electricity. On the other hand, in the countries with the lowest electricity prices, there was little variation between clusters in terms of the volume of energy absorption. Very low taxes and fees were also applied. Maybe that is why electricity prices were very low. The differences resulted from trends in prices, because in Hungary they fell 
by $30 \%$, while in Bulgaria they increased by over $30 \%$. Therefore, the directions of price changes were different.

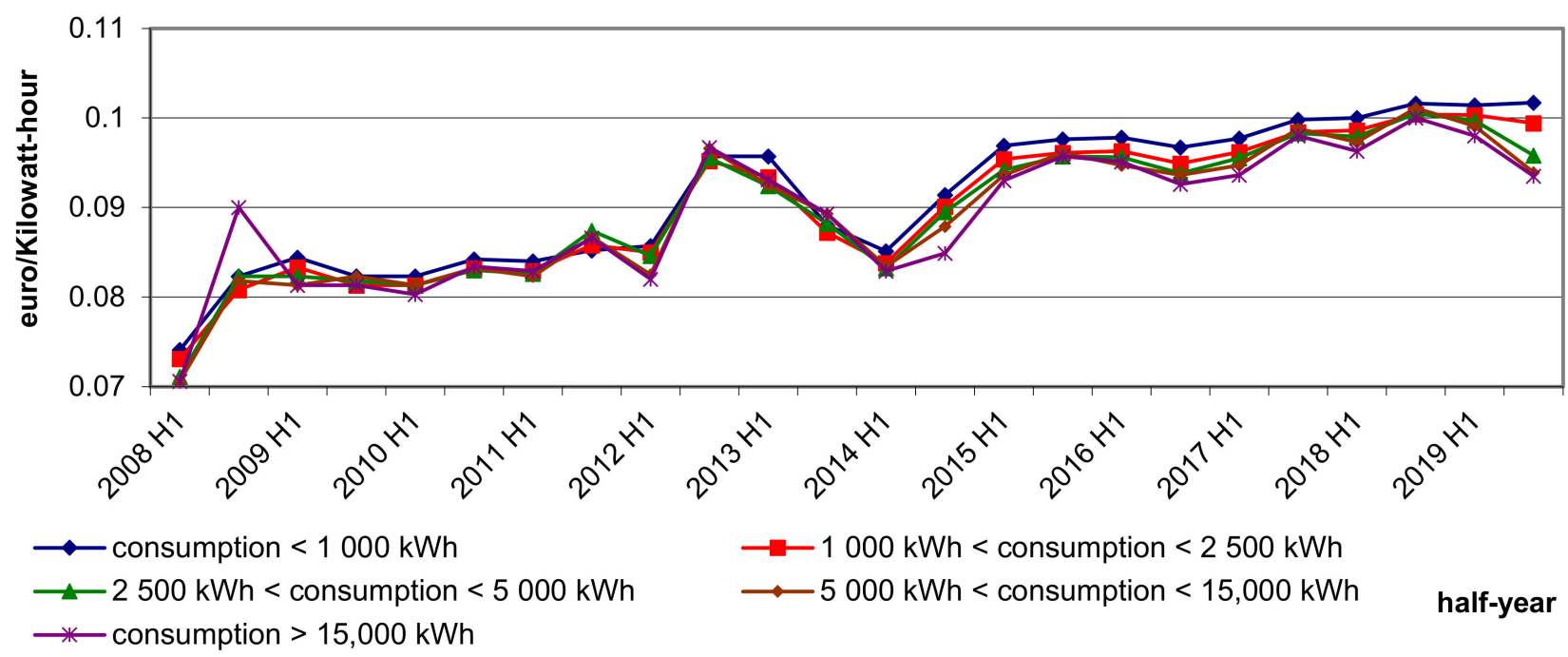

Figure 7. Electricity prices for private customers in Bulgaria in 2008-2019.

\subsection{Directions of Changes of Electric Prices for Households in EU Countries}

In the next stage, the dynamics indicators for electricity prices intended for private households were calculated. Similarly, the division into clusters according to the consumption volume was applied. As the basis the level of prices from 2008 was applied (Table 1). The results were ordered in descending order due to the dynamics for the smallest volume of electricity consumption, i.e., up to $1000 \mathrm{kWh}$. Electricity prices have risen in most EU countries over the past 11 years. In addition to the aforementioned Hungary and Denmark, there were also declines in Ireland. The most significant increase in electricity prices was recorded in Malta for households consuming up to $1000 \mathrm{kWh}$. Prices there increased more than six times. There was only one energy supplier in Malta, which could have had the most significant impact on such a large increase in energy. On the contrary, the level of energy prices doubled in Latvia, Great Britain, and Estonia. In Latvia and Estonia, the markets were dominated by single energy suppliers with a large market share, $63 \%$ and $80 \%$, respectively, in 2019. In Great Britain, the largest supplier had around $20 \%$ of the market share. The shifts in electricity prices may also result from energy policies implemented by individual EU states. Each country should be analyzed individually due to the existing socio-economic circumstances. In general, the largest increases in electricity prices occurred in the economically developed countries of Western Europe. The largest price drops or the smallest increases in developing economies of Central and Eastern Europe. In these countries, there was more significant public pressure to keep electricity prices lower.

\subsection{Variability of Electric Prices for Households in EU Countries}

Then, the coefficients of variation for electricity prices intended for households were calculated. The results, as before, were presented in five groups differing in the volume of energy consumption. The results concern the years 2008-2019 and have been ordered in ascending order according to the volatility of electricity prices in the group of households consuming up to $1000 \mathrm{kWh}$ per year (Table 2). Electricity price volatility was not too great. In many countries, the price change took place twice a year, and the amplitude of these changes was small. As a result, the prices slightly deviated from the average price over the period. The largest price fluctuations occurred in Latvia, Malta, Greece, and Belgium. Slovakia, Poland, the Czech Republic, Croatia, and Bulgaria were the most stable countries regarding energy prices for households. These were economically developing countries that wanted to ensure the stability of electricity prices to their citizens. In general, there was 
no universal trend for all EU states. The reason, except from diverse economic development and applied government policies in these countries, could also be the various levels of energy development, the pressure of society, as well as the social consent to apply various charges in the price of energy, e.g., for the development of renewable energy.

Table 1. Dynamics indicators for electricity prices for household consumers by volume of consumption in EU member states in 2008-2019 (year $2008=100$ ).

\begin{tabular}{|c|c|c|c|c|c|}
\hline \multirow{2}{*}{ Countries } & \multicolumn{5}{|c|}{ Dynamics Factors for Household Consumers in 2008-2019 } \\
\hline & $<1000 \mathrm{kWh}$ & $1000-2500 \mathrm{kWh}$ & $2500-5000 \mathrm{kWh}$ & $5000-15,000 \mathrm{kWh}$ & $>15,000 \mathrm{kWh}$ \\
\hline Malta & 752.36 & 239.74 & 131.42 & 115.97 & 231.69 \\
\hline Latvia & 268.82 & 204.48 & 194.77 & 189.88 & 199.24 \\
\hline United Kingdom & 212.31 & 160.22 & 151.58 & 149.00 & 136.42 \\
\hline Estonia & 194.87 & 176.87 & 173.34 & 170.53 & 182.06 \\
\hline Spain & 186.34 & 186.54 & 175.26 & 160.60 & 151.18 \\
\hline Belgium & 179.96 & 142.68 & 145.03 & 148.59 & 131.53 \\
\hline Finland & 175.43 & 167.19 & 145.79 & 143.95 & 141.17 \\
\hline Italy & 169.54 & 159.86 & 115.26 & 100.69 & 103.78 \\
\hline Cyprus & 167.31 & 134.43 & 125.62 & 121.79 & 118.53 \\
\hline France & 163.45 & 157.90 & 157.71 & 164.56 & 168.28 \\
\hline Slovenia & 162.59 & 157.64 & 145.25 & 136.30 & 126.44 \\
\hline Greece & 162.27 & 177.26 & 148.14 & 129.56 & 146.76 \\
\hline The Netherlands & 161.61 & 136.34 & 116.17 & 109.58 & 109.05 \\
\hline $\mathrm{EU}$ & 152.56 & 145.97 & 136.83 & 132.66 & 130.29 \\
\hline Austria & 145.17 & 122.34 & 116.58 & 111.84 & 106.80 \\
\hline Luxembourg & 142.76 & 116.30 & 109.36 & 105.15 & 138.23 \\
\hline Lithuania & 141.00 & 142.89 & 145.81 & 149.50 & 150.46 \\
\hline Sweden & 140.31 & 128.98 & 122.26 & 118.79 & 111.64 \\
\hline Bulgaria & 137.25 & 135.98 & 134.74 & 133.00 & 132.44 \\
\hline Germany & 133.59 & 135.62 & 133.75 & 132.60 & 123.91 \\
\hline Romania & 132.81 & 132.28 & 133.93 & 137.68 & 134.60 \\
\hline Czechia & 129.05 & 123.61 & 126.34 & 134.65 & 147.50 \\
\hline Denmark & 125.72 & 108.66 & 110.97 & 99.40 & 91.17 \\
\hline Portugal & 113.48 & 142.54 & 147.17 & 156.24 & 157.78 \\
\hline Slovakia & 105.56 & 109.03 & 111.54 & 116.29 & 130.74 \\
\hline Poland & 104.55 & 110.61 & 109.29 & 116.16 & 113.42 \\
\hline Croatia & 103.46 & 128.73 & 133.74 & 138.39 & 141.36 \\
\hline Ireland & 92.56 & 151.84 & 143.92 & 140.52 & 133.60 \\
\hline Hungary & 70.85 & 69.28 & 70.87 & 70.02 & 66.90 \\
\hline
\end{tabular}

Table 2. Coefficients of variation for electricity prices for private customers by volume of consumption in EU states in 2008-2019.

\begin{tabular}{|c|c|c|c|c|c|}
\hline \multirow{2}{*}{ Countries } & \multicolumn{5}{|c|}{ Coefficients of Variation for Electricity Prices for Household Consumers } \\
\hline & $<1000 \mathrm{kWh}$ & $1000-2500 \mathrm{kWh}$ & $2500-5000 \mathrm{kWh}$ & $5000-15,000 \mathrm{kWh}$ & $>15,000 \mathrm{kWh}$ \\
\hline Slovakia & 0.05 & 0.06 & 0.06 & 0.08 & 0.09 \\
\hline Poland & 0.06 & 0.06 & 0.06 & 0.07 & 0.07 \\
\hline Czechia & 0.07 & 0.07 & 0.08 & 0.08 & 0.11 \\
\hline Croatia & 0.07 & 0.10 & 0.08 & 0.08 & 0.09 \\
\hline Portugal & 0.08 & 0.13 & 0.15 & 0.17 & 0.18 \\
\hline Bulgaria & 0.09 & 0.08 & 0.08 & 0.08 & 0.08 \\
\hline Denmark & 0.10 & 0.05 & 0.06 & 0.05 & 0.06 \\
\hline Germany & 0.11 & 0.11 & 0.11 & 0.11 & 0.11 \\
\hline Sweden & 0.11 & 0.08 & 0.07 & 0.07 & 0.07 \\
\hline The Netherlands & 0.11 & 0.14 & 0.08 & 0.06 & 0.21 \\
\hline Romania & 0.11 & 0.11 & 0.11 & 0.11 & 0.12 \\
\hline
\end{tabular}


Table 2. Cont.

\begin{tabular}{|c|c|c|c|c|c|}
\hline \multirow{2}{*}{ Countries } & \multicolumn{5}{|c|}{ Coefficients of Variation for Electricity Prices for Household Consumers } \\
\hline & $<1000 \mathrm{kWh}$ & $1000-2500 \mathrm{kWh}$ & $2500-5000 \mathrm{kWh}$ & $5000-15,000 \mathrm{kWh}$ & $>15,000 \mathrm{kWh}$ \\
\hline Lithuania & 0.12 & 0.12 & 0.12 & 0.13 & 0.14 \\
\hline Luxembourg & 0.12 & 0.05 & 0.04 & 0.05 & 0.08 \\
\hline EU & 0.13 & 0.11 & 0.09 & 0.09 & 0.08 \\
\hline Austria & 0.13 & 0.06 & 0.04 & 0.03 & 0.04 \\
\hline Finland & 0.14 & 0.13 & 0.09 & 0.09 & 0.09 \\
\hline Slovenia & 0.17 & 0.12 & 0.10 & 0.08 & 0.06 \\
\hline Hungary & 0.17 & 0.17 & 0.17 & 0.15 & 0.17 \\
\hline France & 0.18 & 0.14 & 0.14 & 0.15 & 0.15 \\
\hline Estonia & 0.19 & 0.17 & 0.16 & 0.15 & 0.16 \\
\hline Ireland & 0.20 & 0.14 & 0.11 & 0.10 & 0.09 \\
\hline Italy & 0.22 & 0.13 & 0.07 & 0.11 & 0.17 \\
\hline Cyprus & 0.22 & 0.20 & 0.18 & 0.18 & 0.19 \\
\hline Spain & 0.24 & 0.17 & 0.15 & 0.13 & 0.12 \\
\hline United Kingdom & 0.25 & 0.16 & 0.14 & 0.15 & 0.15 \\
\hline Belgium & 0.26 & 0.16 & 0.15 & 0.16 & 0.17 \\
\hline Greece & 0.27 & 0.23 & 0.17 & 0.15 & 0.14 \\
\hline Malta & 0.27 & 0.19 & 0.14 & 0.10 & 0.20 \\
\hline Latvia & 0.30 & 0.20 & 0.18 & 0.17 & 0.17 \\
\hline
\end{tabular}

3.5. Relation between Electric Prices for Households and the Economic and Energy Parameters in the EU

Kendall's tau and Spearman's rank correlation coefficients were computed to find the relationship between the prices of electricity intended for households in the EU and the economic and energy parameters (Tables 3 and 4). $p=0.05$ was used as marginal value of the level of importance. Irrelevant results are highlighted in the table as red font. Correlation coefficients were computed for the entire EU for the whole period of 2008-2019. The research project attempted to check the correlation, which does not suggest that a given factor impacts on another but that there is a significant or minor relationship. In the case of electricity prices for households, the calculations were made using the average annual prices in particular groups that differ in the volume of energy consumption. Electricity prices for private customers were normally distributed. For example, the distribution of electricity prices was also given for households consuming between 2500 and $5000 \mathrm{kWh}$ per year, i.e., for the middle group according to the volume of consumption (Figure 8).

For most parameters, strong association with electricity prices intended for households was found. This relationship was strong or very strong in most cases. Strongly positive relationships were found in the relation of electricity prices and all economic parameters. It was not important whether the parameters apply to the entire EU as a political group or apply per capita. It can therefore be concluded that a higher standard of living was associated with higher electricity prices. The societies of economically developed countries are wealthy and can accept higher energy prices. In contrast, in developing countries, the society is poorer, and people only accept lower electricity prices to match their incomes. Higher imports were also associated with higher consumption. On the other hand, exports proved that the obtained funds were obtained, for example, for the import of goods. Additionally, along with the increase in energy absorption by households, the strength of the association between electricity prices and economic parameters decreased. Such results were noticed in both tests. 
Table 3. Kendall's tau correlation coefficients between energy economy parameters and the electricity prices for private customers in the EU.

\begin{tabular}{|c|c|c|c|c|c|c|c|c|c|c|}
\hline \multirow{3}{*}{ Tested Parameters } & \multicolumn{10}{|c|}{ Kendall's Tau Correlation Coefficient } \\
\hline & \multicolumn{2}{|c|}{$<1000 \mathrm{kWh}$} & \multicolumn{2}{|c|}{$1000-2500 \mathrm{kWh}$} & \multicolumn{2}{|c|}{$2500-5000 \mathrm{kWh}$} & \multicolumn{2}{|c|}{$5000-15,000 \mathrm{kWh}$} & \multicolumn{2}{|c|}{$>15,000 \mathrm{kWh}$} \\
\hline & $\tau$ & $p$-Value & $\tau$ & $p$-Value & $\tau$ & $p$-Value & $\tau$ & $p$-Value & $\tau$ & $p$-Value \\
\hline \multicolumn{11}{|c|}{ Correlation coefficients between electricity prices for household consumers and } \\
\hline GDP value & 0.939 & 0.001 & 0.909 & 0.001 & 0.758 & 0.001 & 0.606 & 0.008 & 0.515 & 0.024 \\
\hline $\begin{array}{l}\text { Final consumption expenditure } \\
\text { of households }\end{array}$ & 0.939 & 0.001 & 0.909 & 0.001 & 0.758 & 0.001 & 0.606 & 0.008 & 0.515 & 0.024 \\
\hline Export of goods and services & 0.939 & 0.001 & 0.909 & 0.001 & 0.758 & 0.001 & 0.606 & 0.008 & 0.515 & 0.024 \\
\hline Import of good and services & 0.909 & 0.001 & 0.879 & 0.001 & 0.727 & 0.001 & 0.576 & 0.011 & 0.485 & 0.034 \\
\hline GDP per capita & 0.939 & 0.001 & 0.909 & 0.001 & 0.758 & 0.001 & 0.606 & 0.008 & 0.515 & 0.024 \\
\hline $\begin{array}{l}\text { Final consumption expenditure of } \\
\text { households per capita }\end{array}$ & 0.939 & 0.001 & 0.909 & 0.001 & 0.758 & 0.001 & 0.606 & 0.008 & 0.515 & 0.024 \\
\hline Total energy consumption & -0.151 & 0.451 & -0.182 & 0.373 & -0.333 & 0.115 & -0.485 & 0.024 & -0.515 & 0.016 \\
\hline $\begin{array}{l}\text { Energy productivity in Euro per } \\
\text { kilogram of oil equivalent }\end{array}$ & 0.970 & 0.001 & 0.939 & 0.001 & 0.788 & 0.001 & 0.636 & 0.005 & 0.545 & 0.016 \\
\hline $\begin{array}{c}\text { Energy productivity in Purchasing power } \\
\text { standard (PPS) per kilogram of } \\
\text { oil equivalent }\end{array}$ & 0.970 & 0.001 & 0.939 & 0.001 & 0.788 & 0.001 & 0.636 & 0.005 & 0.545 & 0.016 \\
\hline $\begin{array}{c}\text { Share of renewable energy in gross final } \\
\text { energy consumption }\end{array}$ & 0.999 & 0.001 & 0.970 & 0.001 & 0.818 & 0.001 & 0.667 & 0.003 & 0.576 & 0.011 \\
\hline $\begin{array}{c}\text { Share of renewable energy in gross final } \\
\text { energy consumption of electricity }\end{array}$ & 0.999 & 0.001 & 0.970 & 0.001 & 0.818 & 0.001 & 0.667 & 0.003 & 0.576 & 0.011 \\
\hline $\begin{array}{c}\text { Greenhouse gas emissions intensity of } \\
\text { energy consumption }\end{array}$ & -0.999 & 0.001 & -0.970 & 0.001 & -0.818 & 0.001 & -0.667 & 0.002 & -0.576 & 0.008 \\
\hline $\begin{array}{l}\text { Final energy consumption in households } \\
\text { per capita }\end{array}$ & -0.595 & 0.006 & -0.629 & 0.004 & -0.687 & 0.002 & -0.595 & 0.006 & -0.565 & 0.009 \\
\hline
\end{tabular}

Another group of parameters concerns energy indicators. A very high positive correlation was found between electricity prices for households and energy production yield in Euro per weight unit of oil equivalent and energy production yield in purchasing power standard (PPS) per weight unit of oil equivalent. The purchasing power standard parameter already considered the differences between countries resulting from different product prices and different levels of wages, i.e., differences in the purchasing power of the society. As a result, the situation in individual countries was somewhat more realistic. Electricity prices were also high in countries with high energy productivity. As a rule, higher productivity was associated with a higher level of economic development. Electricity was not the key factor in many countries, so the total energy consumption parameter was less important. The negative relation was significant only in the case of groups of households consuming more energy. In the parameter related to energy consumption per capita, there were significant negative relationships in all groups of farms. The level of renewable energy utilization in electricity production was significant. In turn, considering the extent of renewable energy utilized in the total energy production, the dependencies were significant. Along with the growth of energy absorption by households, the strength of the relationship between electricity prices and energy parameters decreased. A very strong and negative relationship was found between the energy consumption and the intensity of greenhouse gasses emissions. Lower emissions of greenhouse gases corresponded to higher electricity prices. As a rule, economically developed countries use less harmful technologies to the environment, and those developing countries paid less attention to environmental aspects, including greenhouse gas emissions. 
Table 4. Spearman's rank correlation coefficients between energy economy parameters and the electricity prices for private customers in the EU.

\begin{tabular}{|c|c|c|c|c|c|c|c|c|c|c|}
\hline \multirow{3}{*}{ Tested Parameters } & \multicolumn{10}{|c|}{ Spearman's Rank Correlation Coefficient } \\
\hline & \multicolumn{2}{|c|}{$<1000 \mathrm{kWh}$} & \multicolumn{2}{|c|}{$1000-2500 \mathrm{kWh}$} & \multicolumn{2}{|c|}{$2500-5000 \mathrm{kWh}$} & \multicolumn{2}{|c|}{$5000-15,000 \mathrm{kWh}$} & \multicolumn{2}{|c|}{$>15,000 \mathrm{kWh}$} \\
\hline & $\mathbf{r}_{\mathbf{s}}$ & $p$-Value & $\mathbf{r}_{\mathbf{s}}$ & $p$-Value & $\mathbf{r}_{\mathbf{s}}$ & $p$-Value & $\mathbf{r}_{\mathbf{s}}$ & $p$-Value & $\mathbf{r}_{\mathrm{s}}$ & $p$-Value \\
\hline \multicolumn{11}{|c|}{ Correlation coefficients between electricity prices for household consumers and } \\
\hline GDP value & 0.979 & 0.001 & 0.972 & 0.001 & 0.895 & 0.001 & 0.762 & 0.001 & 0.671 & 0.050 \\
\hline $\begin{array}{l}\text { Final consumption } \\
\text { expenditure of households }\end{array}$ & 0.979 & 0.001 & 0.972 & 0.001 & 0.895 & 0.001 & 0.762 & 0.001 & 0.671 & 0.050 \\
\hline Export of goods and services & 0.979 & 0.001 & 0.972 & 0.001 & 0.895 & 0.001 & 0.762 & 0.001 & 0.671 & 0.050 \\
\hline Import of good and services & 0.972 & 0.001 & 0.965 & 0.001 & 0.888 & 0.001 & 0.741 & 0.001 & 0.650 & 0.050 \\
\hline GDP per capita & 0.979 & 0.001 & 0.972 & 0.001 & 0.895 & 0.001 & 0.762 & 0.001 & 0.671 & 0.050 \\
\hline $\begin{array}{c}\text { Final consumption } \\
\text { expenditure of households } \\
\text { per capita }\end{array}$ & 0.979 & 0.001 & 0.972 & 0.001 & 0.895 & 0.001 & 0.762 & 0.001 & 0.671 & 0.050 \\
\hline Total energy consumption & -0.182 & 0.100 & -0.189 & 0.100 & -0.406 & 0.100 & -0.662 & 0.050 & -0.678 & 0.050 \\
\hline $\begin{array}{l}\text { Energy productivity in Euro } \\
\text { per kilogram of oil equivalent }\end{array}$ & 0.993 & 0.001 & 0.986 & 0.001 & 0.909 & 0.001 & 0.776 & 0.001 & 0.685 & 0.050 \\
\hline $\begin{array}{l}\text { Energy productivity in } \\
\text { purchasing power standard } \\
\text { (PPS) per kilogram of } \\
\text { oil equivalent }\end{array}$ & 0.993 & 0.001 & 0.986 & 0.001 & 0.909 & 0.001 & 0.776 & 0.001 & 0.685 & 0.050 \\
\hline $\begin{array}{l}\text { Share of renewable energy in } \\
\text { gross final } \\
\text { energy consumption }\end{array}$ & 0.999 & 0.001 & 0.993 & 0.001 & 0.916 & 0.001 & 0.783 & 0.001 & 0.692 & 0.050 \\
\hline $\begin{array}{c}\text { Share of renewable energy in } \\
\text { gross final energy } \\
\text { consumption of electricity }\end{array}$ & 0.999 & 0.001 & 0.993 & 0.001 & 0.916 & 0.001 & 0.783 & 0.001 & 0.692 & 0.050 \\
\hline $\begin{array}{l}\text { Greenhouse gas emissions } \\
\text { intensity of } \\
\text { energy consumption }\end{array}$ & -0.999 & 0.001 & 0.993 & 0.001 & -0.916 & 0.001 & -0.783 & 0.001 & -0.692 & 0.050 \\
\hline $\begin{array}{l}\text { Final energy consumption in } \\
\text { households per capita }\end{array}$ & -0.788 & 0.001 & -0.806 & 0.001 & -0.872 & 0.001 & -0.781 & 0.001 & -0.739 & 0.010 \\
\hline
\end{tabular}

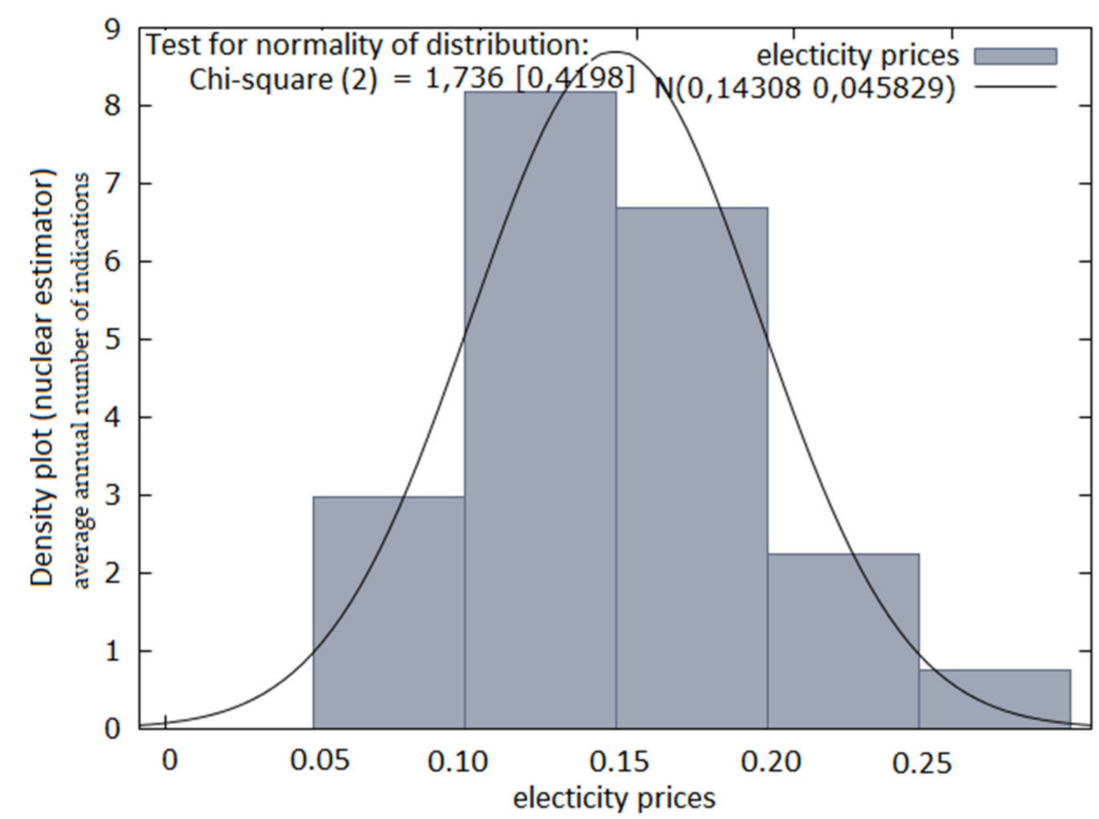

Figure 8. Graph of kernel density estimation for electricity prices for household consumers in a group consuming 2500-5000 kWh in EU in 2008-2019. 


\section{Discussion}

In developed economies' markets, renewable energy resources (especially wind and solar power) reduced electricity prices, and increased their variability. With a small share of renewables, the price volatility decreased [99-107]. The study of the authors of the article also confirmed these dependencies because Western European states, with higher percentage of renewable energy in total energy, were represented by greater electricity prices than Eastern EU states with a lower contribution of renewable energy. The differences in electricity prices in individual countries result from the approach to their determination. Often, the electricity price depends on the node rather than market conditions, i.e., over or under energy. Marginal costs that vary with the technologies and energy sources used are also taken into account. The price of electricity is increasingly dynamically set in realtime depending on energy demand and supply [108-112]. Therefore, there are significant differences in the price of electricity in Western European states, depending on the amount of consumption. In the price of electricity there are also included taxes and tariffs that reflect external environmental costs and effectively reduce energy consumption. Thus, many countries have a double dividend that stimulates economic activity while reducing emissions. Such systems were more effective in economically developed countries than in developing countries [113-117].

In the short run, the low price of electricity may favor economic development. However, the low price of electricity, in the longer term, will encourage expansion of energyintensive industries with low added value, which is not good for the optimization and modernization of the industrial structure. Therefore, the policy of low electricity prices is detrimental to sustainable economic growth in the long term. [118-121]. In the study by the authors of this article, a fairly clear division between developing countries with low electricity prices and economically developed countries with high prices was found. Rising electricity prices are forcing countries to invest in improvement of energy efficiency. Promoted technologies were based on renewable energy that stimulates economic growth [122-125]. The presented relationships are consistent with those obtained during the research of the authors of the article.

Research of other authors also found a high dependence of GDP per capita on energy consumption and electricity prices in households. A higher level of DGP per capita was associated with better energy consumption and higher electricity prices $[66,126]$. Raising electricity prices in many countries is an effective method of increasing energy efficiency. It is performed by using various types of taxes and levies as part of the electricity price [127-130]. There is a belief that electricity prices should take into account all externalities and thus affect consumers. Such an impact is possible, especially in economically developed countries [131].

In the future, electricity prices will be affected by changes taking place in the energy market. Virtual power plants will be created, connecting scattered producers of renewable energy. Thus, intelligent energy networks will be created, and the system will be highly decentralized [132-134]. The structure of devices that use electricity will also change. The greatest consumption will be related to devices using information technology, including mobile. Households will, in a way, depend on these devices and will agree to the prices of electricity. However, the innovations introduced in this industry contribute to the greater energy efficiency of the devices used [135-139].

\section{Conclusions}

The conducted research allowed for drawing several conclusions:

1. Electricity prices in the EU grew steadily. However, there were differences in these rates depending on the volume of consumption. The more electricity a household consumed per year, the less it paid for $1 \mathrm{kWh}$. These regularities were not always met in individual countries, especially in developing countries in Central and Eastern Europe such as Hungary and Bulgaria. Hungary was one of the few countries where electricity prices fell; 
2. Across the EU, electricity prices were growing fastest in households consuming the least energy, i.e., up to $1000 \mathrm{kWh}$, and the slowest in households with the highest consumption, i.e., above $1000 \mathrm{kWh}$. As a result, the disproportions between prices in these groups of households increased. Such regularities occurred especially in highly developed countries such as Denmark and Germany;

3. The highest prices of electricity intended for households were generally found in economically developed states of Western Europe and the lowest in economically developing states of Eastern EU. This is because socio-economic factors are of great importance here;

4. Higher electricity prices for households were associated with better economic parameters of the country, but the strength of this relationship decreased with increasing electricity consumption in households. Thus, the first hypothesis was confirmed. These results confirm the regularity according to which developed countries must have higher energy prices because they will ensure energy transformation, i.e., the implementation of energy-saving technologies. At low prices, such actions would not be economically justified. In highly developed economies, the percentage of taxes and tariffs in the price of electricity was much higher than in developing countries. In Western Europe, there was a differentiation in the amount of taxes and charges depending on the volume of electricity consumption. As a rule, the load increased along with the growth in the amount of consumption. Societies in these countries were more prosperous and aware, so they agreed to additional taxes due to higher energy consumption;

5. Electricity prices for households in the EU countries were not subject to large fluctuations. They were most stable in developing economies, such as Slovakia, Poland, and the Czech Republic, and least stable in highly developed countries such as Malta, Belgium, and Great Britain. Overall, in the EU states, electricity prices for household consumers showed little variability, but the volatility increased with the growth of the level of household energy absorption, especially in the group of highly developed countries. Thus, the second hypothesis was confirmed;

6. Price changes may result from national policy and the type of energy market in a given country. For example, in the countries with dominant position of one energy supplier, there may have been significant increases in electricity prices. On the contrary, governments of individual states can also influence electricity prices in other countries, especially where the pressure of society to maintain lower electricity prices is greater;

7. Subsequent research may focus on the relationship between energy prices and the implementation of climate policy in individual countries. One can compare individual countries with each other or groupings of countries. Countries can also be grouped according to the level of economic development. Research may also focus on the importance of various types of taxes in the price of energy. By definition, this type of taxes should be spent mostly on improving energy efficiency, i.e., restructuring the energy sector. Such actions, in turn, will affect the implementation of climate commitments by individual countries.

Author Contributions: Conceptualization, T.R.; methodology, T.R.; software, T.R.; validation, T.R.; formal analysis, T.R.; investigation, T.R.; resources, T.R.; data curation, writing-original draft preparation, T.R., P.B., B.G., P.G., A.M.-K. and J.K.; writing-review and editing, T.R., P.B., B.G., P.G., A.M.-K., J.K., D.J.G.-D. and K.W.; visualization, T.R.; supervision, T.R.; project administration, T.R. All authors have read and agreed to the published version of the manuscript.

Funding: This research received no external funding.

Institutional Review Board Statement: Not applicable.

Informed Consent Statement: Not applicable.

Conflicts of Interest: The authors declare no conflict of interest. 


\section{References}

1. Khan, K.A.; Hasan, M.; Islam, M.A.; Alim, M.A.; Asma, U.; Hassan, L.; Ali, M.H. A study on conventional energy sources for power production. Int. J. Adv. Res. Innov. Ideas Educ. 2018, 4, 214-228.

2. Tareen, W.U.K.; Anjum, Z.; Yasin, N.; Siddiqui, L.; Farhat, I.; Malik, S.A.; Aamir, M. The prospective non-conventional alternate and renewable energy sources in Pakistan-A focus on biomass energy for power generation, transportation, and industrial fuel. Energies 2018, 11, 2431. [CrossRef]

3. Rodríguez-Monroy, C.; Mármol-Acitores, G.; Nilsson-Cifuentes, G. Electricity generation in Chile using non-conventional renewable energy sources-A focus on biomass. Renew. Sustain. Energy Rev. 2018, 81, 937-945. [CrossRef]

4. Owusu, P.A.; Asumadu-Sarkodie, S. A review of renewable energy sources, sustainability issues and climate change mitigation. Cogent Eng. 2016, 3, 1167990. [CrossRef]

5. Liang, X. Emerging power quality challenges due to integration of renewable energy sources. IEEE Trans. Ind. Appl. 2016, 53, 855-866. [CrossRef]

6. Rokicki, T.; Perkowska, A. Changes in Energy Supplies in the Countries of the Visegrad Group. Sustainability 2020, $12,7916$. [CrossRef]

7. Rokicki, T.; Perkowska, A. Diversity and Changes in the Energy Balance in EU Countries. Energies 2021, 14, 1098. [CrossRef]

8. Rokicki, T.; Perkowska, A.; Klepacki, B.; Bórawski, P.; Bełdycka-Bórawska, A.; Michalski, K. Changes in Energy Consumption in Agriculture in the EU Countries. Energies 2021, 14, 1570. [CrossRef]

9. Gostkowski, M.; Rokicki, T.; Ochnio, L.; Koszela, G.; Wojtczuk, K.; Ratajczak, M.; Szczepaniuk, H.; Bórawski, P.; BełdyckaBórawska, A. Clustering Analysis of Energy Consumption in the Countries of the Visegrad Group. Energies 2021, $14,5612$. [CrossRef]

10. Rokicki, T.; Ratajczak, M.; Bórawski, P.; Bełdycka-Bórawska, A.; Gradziuk, B.; Gradziuk, P.; Siedlecka, A. Energy Self-Subsistence of Agriculture in EU Countries. Energies 2021, 14, 3014. [CrossRef]

11. Lockwood, M.; Froggatt, A.; Wright, G.; Dutton, J. The implications of Brexit for the electricity sector in Great Britain: Trade-offs between market integration and policy influence. Energy Policy 2017, 110, 137-143. [CrossRef]

12. Cox, E. Assessing long-term energy security: The case of electricity in the United Kingdom. Renew. Sustain. Energy Rev. 2018, 82, 2287-2299. [CrossRef]

13. Rokicki, T.; Koszela, G.; Ochnio, L.; Wojtczuk, K.; Ratajczak, M.; Szczepaniuk, H.; Michalski, K.; Bórawski, P.; Bełdycka-Bórawska, A. Diversity and Changes in Energy Consumption by Transport in EU Countries. Energies 2021, 14, 5414. [CrossRef]

14. Van den Bergh, K.; Delarue, E.; D'haeseleer, W. Impact of renewables deployment on the $\mathrm{CO}_{2}$ price and the $\mathrm{CO}_{2}$ emissions in the European electricity sector. Energy Policy 2013, 63, 1021-1031. [CrossRef]

15. Thema, J.; Suerkemper, F.; Grave, K.; Amelung, A. The impact of electricity demand reduction policies on the EU-ETS: Modelling electricity and carbon prices and the effect on industrial competitiveness. Energy Policy 2013, 60, 656-666. [CrossRef]

16. Strambo, C.; Nilsson, M.; Månsson, A. Coherent or inconsistent? Assessing energy security and climate policy interaction within the European Union. Energy Res. Soc. Sci. 2015, 8, 1-12. [CrossRef]

17. Antonioli, D.; Borghesi, S.; D'Amato, A.; Gilli, M.; Mazzanti, M.; Nicolli, F. Analysing the interactions of energy and climate policies in a broad policy 'optimality' framework: The Italian case study. J. Integr. Environ. Sci. 2014, 11, 205-224. [CrossRef]

18. Leal-Arcas, R. Towards Sustainability in Trade, Energy and Climate. Mod. Environ. Sci. Eng. 2020, 6, 1-30. [CrossRef]

19. Leal-Arcas, R.; Lesniewska, F.; Proedrou, F. Prosumers: New actors in EU energy security. In Netherlands Yearbook of International Law; TMC Asser Press: The Hague, The Netherlands, 2017; pp. 139-172.

20. De Almeida, A.; Fonseca, P.; Schlomann, B.; Feilberg, N. Characterization of the household electricity consumption in the EU, potential energy savings and specific policy recommendations. Energy Build. 2011, 43, 1884-1894. [CrossRef]

21. Pereira, G.I.; da Silva, P.P.; Soule, D. Policy-adaptation for a smarter and more sustainable EU electricity distribution industry: A foresight analysis. Environ. Dev. Sustain. 2018, 20, 231-267. [CrossRef]

22. Soares, N.; Martins, A.G.; Carvalho, A.L.; Caldeira, C.; Du, C.; Castanheira, É.; Ferreira, J.P. The challenging paradigm of interrelated energy systems towards a more sustainable future. Renew. Sustain. Energy Rev. 2018, 95, 171-193. [CrossRef]

23. Pereira, G.; da Silva, P.P.; Soule, D. Designing Markets for Innovative Electricity Services in the EU: The Roles of Policy, Technology, and Utility Capabilities. In Consumer, Prosumer, Prosumager: How Service Innovations Will Disrupt the Utility Business Model; Academic Press: Cambridge, MA, USA, 2019; Volume 355.

24. Kang, J.N.; Wei, Y.M.; Liu, L.C.; Han, R.; Yu, B.Y.; Wang, J.W. Energy systems for climate change mitigation: A systematic review. Appl. Energy 2020, 263, 114602. [CrossRef]

25. Marques, G.S.; Dias, M.A.P.; Vianna, J.N.S. Innovation in the electricity sector in the age of Disruptive Technologies and renewable Energy Sources: A Bibliometric study from 1991 to 2019. Int. J. Adv. Eng. Res. Sci. 2020, 7, 261-272. [CrossRef]

26. Rokicki, T.; Perkowska, A.; Klepacki, B.; Szczepaniuk, H.; Szczepaniuk, E.K.; Bereziński, S.; Ziółkowska, P. The Importance of Higher Education in the EU Countries in Achieving the Objectives of the Circular Economy in the Energy Sector. Energies 2020, 13, 4407. [CrossRef]

27. Bełdycka-Bórawska, A.; Bórawski, P.; Borychowski, M.; Wyszomierski, R.; Bórawski, M.B.; Rokicki, T.; Ochnio, L.; Jankowski, K.; Mickiewicz, B.; Dunn, J.W. Development of Solid Biomass Production in Poland, Especially Pellet, in the Context of the World's and the European Union's Climate and Energy Policies. Energies 2021, 14, 3587. [CrossRef] 
28. European Union. Directive 96/92/EC of the European Parliament and of the Council of 19 December 1996 concerning common rules for the internal market in electricity. Off. J. Eur. Communities 1996, L27, 20-29.

29. European Union. Directive 2003/54/EC of the European Parliament and of the Council of 26 June 2003 concerning common rules for the internal market in electricity and repealing Directive 96/92/EC. Off. J. Eur. Union 2003, L176, 37-55.

30. European Union. Directive of 2009/72/EC of the European Parliament and of the Council of 13 July 2009 concerning common rules for the internal market in electricity and repealing Directive 2003/54/EC. Off. J. Eur. Union 2009, 211, 55-93.

31. European Commission. Energy 2020. A Strategy for Competitive, Sustainable and Secure Energy; European Commission: Brussels, Belgium, 2010.

32. European Commission. Energy Roadmap 2050; European Commission: Brussels, Belgium, 2011.

33. European Commission. Energy Union Package. A Framework Strategy for a Resilient Energy Union with a Forward Looking Climate Change Policy; European Commission: Brussels, Belgium, 2015.

34. European Commission. Clean Energy for All Europeans. Communication from the Commission to the European Parliament, the Council, the European Economic and Social Committee, the Committee of the Regions and the European Investment Bank; European Commission: Brussels, Belgium, 2016.

35. Hortaçsu, A.; Madanizadeh, S.A.; Puller, S.L. Power to choose? An analysis of consumer inertia in the residential electricity market. Am. Econ. J. Econ. Policy 2017, 9, 192-226. [CrossRef]

36. Grubb, M.D. Failing to choose the best price: Theory, evidence, and policy. Rev. Ind. Organ. 2015, 47, 303-340. [CrossRef]

37. Shin, K.J.; Managi, S. Liberalization of a retail electricity market: Consumer satisfaction and household switching behavior in Japan. Energy Policy 2017, 110, 675-685. [CrossRef]

38. Deller, D.; Giulietti, M.; Loomes, G.; Price, C.W.; Moniche, A.; Jeon, J.Y. Switching energy suppliers: It's not all about the money. Energy J. 2017, 42, 95-120. [CrossRef]

39. Flores, M.; Price, C.W. The role of attitudes and marketing in consumer behaviours in the british retail electricity market. Energy J. 2018, 39, 153-179. [CrossRef]

40. Frondel, M.; Kussel, G. Switching on Electricity Demand Response: Evidence for German Households. Energy J. 2019, 40, 1-16. [CrossRef]

41. Giulietti, M.; Waterson, M.; Wildenbeest, M. Estimation of search frictions in the british electricity market. J. Ind. Econ. 2014, 62, 555-590. [CrossRef]

42. Ndebele, T.; Marsh, D.; Scarpa, R. Consumer switching in retail electricity markets: Is price all that matters? Energy Econ. 2019, 83, 88-103. [CrossRef]

43. Moreno-Munoz, A.; Bellido-Outeirino, F.J.; Siano, P.; Gomez-Nieto, M.A. Mobile social media for smart grids customer engagement: Emerging trends and challenges. Renew. Sustain. Energy Rev. 2016, 53, 1611-1616. [CrossRef]

44. Johnson, D.; Horton, E.; Mulcahy, R.; Foth, M. Gamification and serious games within the domain of domestic energy consumption: A systematic review. Renew. Sustain. Energy Rev. 2017, 73, 249-264. [CrossRef]

45. Espe, E.; Potdar, V.; Chang, E. Prosumer communities and relationships in smart grids: A literature review, evolution and future directions. Energies 2018, 11, 2528. [CrossRef]

46. Albaker, A.; Khodaei, A. Elevating prosumers to provisional microgrids. In Proceedings of the 2017 IEEE Power \& Energy Society General Meeting, Chicago, IL, USA, 16-20 July 2017; pp. 1-5.

47. Klepacki, B.; Kusto, B.; Bórawski, P.; Bełdycka-Bórawska, A.; Michalski, K.; Perkowska, A.; Rokicki, T. Investments in Renewable Energy Sources in Basic Units of Local Government in Rural Areas. Energies 2021, 14, 3170. [CrossRef]

48. Rokicki, T.; Perkowska, A.; Ratajczak, M. Differentiation in Healthcare Financing in EU Countries. Sustainability 2021, 13, 251. [CrossRef]

49. Hau, V.B.; Husein, M.; Chung, I.-Y.; Won, D.-J.; Torre, W.; Nguyen, T. Analyzing the Impact of Renewable Energy Incentives and Parameter Uncertainties on Financial Feasibility of a Campus Microgrid. Energies 2018, 11, 2446. [CrossRef]

50. Luna, A.C.; Diaz, N.L.; Graells, M.; Vasquez, J.C.; Guerrero, J.M. Mixed-Integer-Linear- Programming-Based Energy Management System for Hybrid PV-Wind-Battery Microgrids: Modeling, Design, and Experimental Verification. IEEE Trans. Power Electron. 2017, 32, 2769-2783. [CrossRef]

51. Kharseh, M.; Wallbaum, H. How Adding a Battery to a Grid-Connected Photovoltaic System Can Increase its Economic Performance: A Comparison of Different Scenarios. Energies 2019, 12, 30. [CrossRef]

52. González-Romera, E.; Ruiz-Cortés, M.; Milanés-Montero, M.I.; Barrero-González, F.; Romero-Cadaval, E.; Lopes, R.A.; Martins, J. Advantages of minimizing energy exchange instead of energy cost in prosumer microgrids. Energies 2019, 12, 719. [CrossRef]

53. Xenias, D.; Axon, C.J.; Whitmarsh, L.; Connor, P.M.; Balta-Ozkan, N.; Spence, A. UK smart grid development: An expert assessment of the benefits, pitfalls and functions. Renew. Energy 2015, 81, 89-102. [CrossRef]

54. Rezkallah, M.; Chandra, A.; Singh, B.; Singh, S. Microgrid: Configurations, Control and Applications. IEEE Trans. Smart Grid 2017, 10, 1290-1302. [CrossRef]

55. Wang, K.; Qiu, X.; Guo, S.; Qi, F. Fault Tolerance Oriented Sensors Relay Monitoring Mechanism for Overhead Transmission Line in Smart Grid. IEEE Sens. J. 2015, 15, 1982-1991. [CrossRef]

56. Alves, G.; Marques, D.; Silva, I.; Guedes, L.A.; da Silva, M.D.G. A Methodology for Dependability Evaluation of Smart Grids. Energies 2019, 12, 1817. [CrossRef] 
57. Albaker, A.; Khodaei, A. Valuation of microgrid unused capacity in islanded operation. In Proceedings of the 2017 North American Power Symposium (NAPS), Morgantown, WV, USA, 17-19 September 2017; pp. 1-6. [CrossRef]

58. Choi, J.; Shin, Y.; Choi, M.; Park, W.; Lee, I. Robust Control of a Microgrid Energy Storage System using Various Approaches. IEEE Trans. Smart Grid 2019, 10, 10-2702. [CrossRef]

59. Wang, H.; Huang, J. Incentivizing Energy Trading for Interconnected Microgrids. IEEE Trans. Smart Grid 2018, 9, $2647-2657$. [CrossRef]

60. González-Romera, E.; Romero-Cadaval, E.; Garrido-Zafra, J.; Florencias-Oliveros, O.; Ruiz-Cortés, M.; Moreno-Munoz, A.; González-de-la-Rosa, J.J. Demand and Storage Management in a Prosumer Nanogrid Based on Energy Forecasting. Electronics 2020, 9, 363. [CrossRef]

61. Lucia, J.J.; Schwartz, E.S. Electricity Prices and Power Derivatives: Evidence from the Nordic Power Exchange. Rev. Deliv. Res. 2002, 5, 5-50.

62. Huisman, R.; Mahieu, R. Regime jumps in electricity prices. Energy Econ. 2003, 25, 425-434. [CrossRef]

63. Jaimungal, S.; Surkov, V. Lévy-based cross-commodity models and derivative valuation. SIAM J. Financ. Math. 2011, 2, 464-487. [CrossRef]

64. Raviv, E.; Bouwman, K.E.; van Dijk, D. Forecasting day-ahead electricity prices: Utilizing hourly prices. Energy Econ. 2015, 50, 227-239. [CrossRef]

65. Maekawa, J.; Hai, B.H.; Shinkuma, S.; Shimada, K. The Effect of Renewable Energy Generation on the Electric Power Spot Price of the Japan Electric Power Exchange. Energies 2018, 11, 2215. [CrossRef]

66. Moreno, B.; López, A.J.; García-Álvarez, M.T. The electricity prices in the European Union. The role of renewable energies and regulatory electric market reforms. Energy 2012, 48, 307-313. [CrossRef]

67. Verbič, M.; Filipović, S.; Radovanović, M. Electricity prices and energy intensity in Europe. Util. Policy 2017, 47, 58-68. [CrossRef]

68. Price, C.W.W.; Zhu, M. Non-discrimination clauses: Their effect on British retail energy prices. Energy J. 2016, 37, 111-132.

69. Littlechild, S. The CMA energy market investigation, the well-functioning market, Ofgem, Government and behavioral economics. Eur. Compet. J. 2015, 11, 574-636. [CrossRef]

70. Price, C.W. Back to the future? Regulating residential energy markets. Int. J. Econ. Bus. 2018, 25, 147-155. [CrossRef]

71. Bacon, R.W. Rockets and feathers: The asymmetric speed of adjustment of UK retail gasoline prices to cost changes. Energy Econ. 1991, 13, 211-218. [CrossRef]

72. Borenstein, S.; Cameron, A.C.; Gilbert, R. Do gasoline prices respond chasymmetrically to crude oil price changes? Q. J. Econ. 1997, 112, 305-339. [CrossRef]

73. Deltas, G. Retail gasoline price dynamics and local market power. J. Ind. Econ. 2018, 56, 613-628. [CrossRef]

74. Heim, S. Rockets and Feathers: Asymmetric Pricing and Consumer Search-Evidence from Electricity Retailing; ZEW-Centre for European Economic Research: Mannheim, Germany, 2019; Discussion Paper No. 16-070.

75. Lewis, M.S. Asymmetric price adjustment and consumer search: An examination of the retail gasoline market. J. Econ. Manag. Strategy 2011, 20, 409-449. [CrossRef]

76. Cabral, L.; Fishman, A. Business as usual: A consumer search theory of sticky prices and asymmetric price adjustment. Int. J. Ind. Organ. 2012, 30, 371-376. [CrossRef]

77. Scotti, D.; Volta, N. Price asymmetries in European airfares. Econ. Transp. 2018, 14, 42-52. [CrossRef]

78. Lanot, G.; Vesterberg, M. An empirical model of the decision to switch between electricity price contracts. J. Bus. Anal. 2019, 2, 24-46. [CrossRef]

79. Schleich, J.; Faure, C.; Gassmann, X. Household internal and external electricity contract switching in EU countries. Appl. Econ. 2019, 51, 103-116. [CrossRef]

80. Vesterberg, M. The effect of price on electricity contract choice. Energy Econ. 2018, 69, 59-70. [CrossRef]

81. Kažukauskas, A.; Broberg, T. Perceptions and Inattention in Private Electricity Consumption. 2016. Available online: https: / / ssrn.com/abstract=2743227 (accessed on 1 September 2021).

82. Keefer, Q.; Rustamov, G. Limited attention in residential energy markets: A regression discontinuity approach. Empir. Econ. 2018, 55, 993-1017. [CrossRef]

83. Vesterberg, M. The hourly income elasticity of electricity. Energy Econ. 2016, 59, 188-197. [CrossRef]

84. Stojanovski, O.; Leslie, G.; Wolak, F.; Huerta Wong, J.E.; Thurber, M.C. Increasing the Energy Cognizance of Electricity Consumers in Mexico: Results from a Field Experiment. J. Environ. Econ. Manag. 2020, 102, 102323. [CrossRef]

85. Allcott, H. Social norms and energy conservation. J. Public Econ. 2011, 95, 1082-1095. [CrossRef]

86. Allcott, H.; Rogers, T. The short-run and long-run effects of behavioral interventions: Experimental evidence from energy conservation. Am. Econ. Rev. 2014, 104, 3003-3037. [CrossRef]

87. Chen, V.L.; Delmas, M.A.; Locke, S.L.; Singh, A. Information strategies for energy conservation: A field experiment in India. Energy Econ. 2017, 68, 215-227. [CrossRef]

88. Chen, V.L.; Delmas, M.A.; Locke, S.L.; Singh, A. Dataset on information strategies for energy conservation: A field experiment in India. Data Brief 2018, 16, 713-716. [CrossRef]

89. Ferraro, P.J.; Price, M.K. Using nonpecuniary strategies to influence behavior: Evidence from a large-scale field experiment. Rev. Econ. Stat. 2013, 95, 64-73. [CrossRef] 
90. Ito, K.; Ida, T.; Tanaka, M. Moral suasion and economic incentives: Field experimental evidence from energy demand. Am. Econ. J. Econ. Policy 2018, 10, 240-267. [CrossRef]

91. Jessoe, K.; Rapson, D. Knowledge is (less) power: Experimental evidence from residential energy use. Am. Econ. Rev. 2014, 104, 1417-1438. [CrossRef]

92. Frondel, M.; Kussel, G.; Sommer, S. Heterogeneity in the price response of residential electricity demand: A dynamic approach for Germany. Resour. Energy Econ. 2019, 57, 119-134. [CrossRef]

93. Kostakis, I. Socio-demographic determinants of household electricity consumption: Evidence from Greece using quantile regression analysis. Curr. Res. Environ. Sustain. 2020, 1, 23-30. [CrossRef]

94. Chetty, R.; Looney, A.; Kroft, K. Salience and taxation: Theory and evidence. Am. Econ. Rev. 2009, 99, 1145-1177. [CrossRef]

95. Starzyńska, W. Statystyka Praktyczna; Wydawnictwo Naukowe PWN: Warsaw, Poland, 2002; p. 102.

96. Abdi, H. Coefficient of Variation. Encycl. Res. Des. 2010, 1, 169-171.

97. Kendall, M.G. Rank Correlation Methods; Griffin: London, UK, 1955; Volume 19.

98. Spearman, C. The proof and measurement of association between two things. Am. J. Psychol. 1904, 15, 72-101. [CrossRef]

99. Ketterer, J.C. The impact of wind power generation on the electricity price in Germany. Energy Econ. 2014, 44, 270-280. [CrossRef]

100. Clò, S.; Cataldi, A.; Zoppoli, P. The merit-order effect in the Italian power market: The impact of solar and wind generation on national wholesale electricity prices. Energy Policy 2015, 77, 79-88. [CrossRef]

101. Martinez-Anido, C.B.; Brinkman, G.; Hodge, B.M. The impact of wind power on electricity prices. Renew. Energy 2016, 94, 474-487. [CrossRef]

102. Ballester, C.; Furió, D. Effects of renewables on the stylized facts of electricity prices. Renew. Sustain. Energy Rev. 2015, 52, 1596-1609. [CrossRef]

103. Cruz, A.; Muñoz, A.; Zamora, J.L.; Espínola, R. The effect of wind generation and weekday on Spanish electricity spot price forecasting. Electr. Power Syst. Res. 2011, 81, 1924-1935. [CrossRef]

104. Milstein, I.; Tishler, A. Can price volatility enhance market power? The case of renewable technologies in competitive electricity markets. Resour. Energy Econ. 2015, 41, 70-90. [CrossRef]

105. Kyritsis, E.; Andersson, J.; Serletis, A. Electricity prices, large-scale renewable integration, and policy implications. Energy Policy 2017, 101, 550-560. [CrossRef]

106. Wozabal, D.; Graf, C.; Hirschmann, D. The effect of intermittent renewables on the electricity price variance. OR Spectr. 2016, 38, 687-709. [CrossRef]

107. Mosquera-López, S.; Nursimulu, A. Drivers of electricity price dynamics: Comparative analysis of spot and futures markets. Energy Policy 2019, 126, 76-87. [CrossRef]

108. Wang, Y.; Yang, Z.; Yu, J.; Fang, X. Revisit the electricity price formulation: A formal definition, proofs, and examples. Energy 2020, 200, 117542. [CrossRef]

109. Karhinen, S.; Huuki, H. How are the long distances between renewable energy sources and load centres reflected in locational marginal prices? Energy 2020, 210, 118546. [CrossRef]

110. Ruokamo, E.; Kopsakangas-Savolainen, M.; Meriläinen, T.; Svento, R. Towards flexible energy demand-Preferences for dynamic contracts, services and emissions reductions. Energy Econ. 2019, 84, 104522. [CrossRef]

111. Dietrich, K.; Leuthold, F.; Weigt, H. Will the market get it right? The placing of new power plants in Germany. Z. Energ. 2010, 34, 255-265. [CrossRef]

112. Egerer, J.; Weibezahn, J.; Hermann, H. Two price zones for the German electricity market-Market implications and distributional effects. Energy Econ. 2016, 59, 365-381. [CrossRef]

113. Bor, Y.J.; Huang, Y. Energy taxation and the double dividend effect in Taiwan's energy conservation policy-An empirical study using a computable general equilibrium model. Energy Policy 2010, 38, 2086-2100. [CrossRef]

114. Allan, G.; Lecca, P.; McGregor, P.; Swales, K. The economic and environmental impact of a carbon tax for Scotland: A computable general equilibrium analysis. Ecol. Econ. 2014, 100, 40-50. [CrossRef]

115. Ciaschini, M.; Pretaroli, R.; Severini, F.; Socci, C. Regional double dividend from environmental tax reform: An application for the Italian economy. Res. Econ. 2012, 66, 273-283. [CrossRef]

116. Solaymani, S. Carbon and energy taxes in a small and open country. Glob. J. Environ. Sci. Manag. 2017, 3, 51-62.

117. Wesseh, P.K., Jr.; Lin, B. Environmental policy and 'double dividend' in a transitional economy. Energy Policy 2019, $134,110947$. [CrossRef]

118. He, W.; Zhang, C.; Hao, R. Analysis of electricity price policy and economic growth. J. Sci. Ind. Res. 2015, 7, 11-18.

119. Khobai, H.; Mugano, G.; Le Roux, P. The impact of electricity price on economic growth in South Africa. Int. J. Energy Econ. Policy 2017, 7, 108-116.

120. Odhiambo, N.M. Energy consumption, prices and economic growth in three SSA countries: A comparative study. Energy Policy 2010, 38, 2463-2469. [CrossRef]

121. Ai, H.; Xiong, S.; Li, K.; Jia, P. Electricity price and industrial green productivity: Does the "low-electricity price trap" exist? Energy 2020, 207, 118239. [CrossRef]

122. Aydin, M. Renewable and non-renewable electricity consumption-economic growth nexus: Evidence from OECD countries. Renew. Energy 2019, 136, 599-606. [CrossRef] 
123. Atems, B.; Hotaling, C. The effect of renewable and nonrenewable electricity generation on economic growth. Energy Policy 2018, 112, 111-118. [CrossRef]

124. Su, Y.W.; Yang, H.Y.; Lin, C.H. Increase of electricity price and energy efficiency: Analysis using the macroeconomic interindustry model of Taiwan. Econ. Syst. Res. 2017, 29, 430-451. [CrossRef]

125. Pezzutto, S.; Grilli, G.; Zambotti, S.; Dunjic, S. Forecasting Electricity Market Price for End Users in EU28 until $2020-M a i n$ Factors of Influence. Energies 2018, 11, 1460. [CrossRef]

126. Jimenez, R.; Mercado, J. Energy intensity: A decomposition and counterfactual exercise for Latin American countries. Energy Economics 2014, 42, 161-171. [CrossRef]

127. Cornillie, J.; Fankhauser, S. The energy intensity of transition countries. Energy Econ. 2004, 26, 283-295. [CrossRef]

128. Fisher-Vanden, K.; Jefferson, G.H.; Liu, H.; Tao, Q. What is driving China's decline in energy intensity? Resour. Energy Econ. 2004, 26, 77-97. [CrossRef]

129. Hang, L.; Tu, M. The impacts of energy prices on energy intensity: Evidence from China. Energy Policy 2007, 35, 2978-2988. [CrossRef]

130. Birol, F.; Keppler, J.H. Prices, technology development and the rebound effect. Energy Policy 2000, 28, 457-469. [CrossRef]

131. Azevedo, I.M.L.; Morgan, M.G.; Lave, L. Residential and regional electricity consumption in the US and EU: How much will higher prices reduce $\mathrm{CO}_{2}$ emissions? Electr. J. 2011, 24, 21-29.

132. Moreno, B.; Díaz, G. The impact of virtual power plant technology composition on wholesale electricity prices: A comparative study of some European Union electricity markets. Renew. Sustain. Energy Rev. 2019, 99, 100-108. [CrossRef]

133. Bellocchi, S.; Manno, M.; Noussan, M.; Vellini, M. Impact of Grid-Scale Electricity Storage and Electric Vehicles on Renewable Energy Penetration: A Case Study for Italy. Energies 2019, 12, 1303. [CrossRef]

134. Maximov, S.A.; Harrison, G.P.; Friedrich, D. Long Term Impact of Grid Level Energy Storage on Renewable Energy Penetration and Emissions in the Chilean Electric System. Energies 2019, 12, 1070. [CrossRef]

135. Andrae, A.S.G.; Edler, T. On Global Electricity Usage of Communication Technology: Trends to 2030. Challenges 2015, 6, 117-157. [CrossRef]

136. Morley, J.; Widdicks, K.; Hazas, M. Digitalisation, energy and data demand: The impact of Internet traffic on overall and peak electricity consumption. Energy Res. Soc. Sci. 2018, 38, 128-137. [CrossRef]

137. Pelau, C.; Acatrinei, C. The Paradox of Energy Consumption Decrease in the Transition Period towards a Digital Society. Energies 2019, 12, 1428. [CrossRef]

138. Andrae, A.S.; Xia, M.; Zhang, J.; Tang, X. Practical eco-design and eco-innovation of consumer electronics-The case of mobile phones. Challenges 2016, 7, 3. [CrossRef]

139. Pihkola, H.; Hongisto, M.; Apilo, O.; Lasanen, M. Evaluating the Energy Consumption of Mobile Data Transfer-From Technology Development to Consumer Behaviour and Life Cycle Thinking. Sustainability 2018, 10, 2494. [CrossRef] 